\title{
Diabetes and cardiovascular disease: inter-relation of risk factors and treatment
}

\author{
Aman Sharma* ${ }^{*}$, Shweta Mittal, Rohan Aggarwal and Meenakshi K. Chauhan
}

\begin{abstract}
Background: The diabetes mellitus prevalence is still advancing and increasingly becoming one of the globally most severe and expensive chronic illnesses. The strong correlation between diabetes as well as the most prominent reason for diabetes and death in diabetic patients is cardiovascular disorders. Health conditions like dyslipidemia, hypertension, obesity, and other factors of risk like the risk of cardiovascular are frequent in diabetic persons and raise the likelihood of heart attacks.

Main text: In particular, several researchers have found diabetes mellitus-related biochemical pathways that raise the likelihood of cardiovascular disorder in people with diabetes individually. This review describes diabetescardiovascular disorder relationships, explores potential therapeutic mechanisms, addresses existing treatment, care, and describes the directions for the future for study.

Conclusion: Thus, in individuals with diabetes, it is important to concentrate on cardiovascular threat variables to reduce the illness's lasting cardiovascular complications. Further work to enhance knowledge of the disease state and its impact on cardiovascular function is required to boost medical treatment and cardiovascular disorders result in people with diabetes.
\end{abstract}

Keywords: Diabetes, Treatment, Mechanism, Risk factors, Cardiovascular disorders

\section{Background}

Globally, there is significantly higher diabetes mellitus (DM) prevalence. The worldwide incidence of DM has grown significantly in the past 30 years and projections suggest that such numbers are only growing significantly [1]. The new global projections of DM are 591 million ( 1 out of 10 persons) by 2035 as calculated by the Federation of International Diabetes [2]. Type 2-DM has a comparatively larger international impact on the increased incidence of DM than type 1-DM [1].

As a result of the rising incidence of DM, the individual, and the medical system is faced with substantial economic burdens. In the western world, mean DM

\footnotetext{
* Correspondence: amans2702@gmail.com

Department of Pharmaceutics, Delhi Institute of Pharmaceutical Sciences and Research, Mehrauli - Badarpur Rd, Sector 3, Pushp Vihar, New Delhi 110017,
} India

(c) The Author(s). 2020 Open Access This article is licensed under a Creative Commons Attribution 4.0 International License which permits use, sharing, adaptation, distribution and reproduction in any medium or format, as long as you give appropriate credit to the original author(s) and the source, provide a link to the Creative Commons licence, and indicate if changes were made. The images or other third party material in this article are included in the article's Creative Commons licence, unless indicated otherwise in a credit line to the material. If material is not included in the article's Creative Commons licence and your intended use is not permitted by statutory regulation or exceeds the permitted use, you will need to obtain permission directly from the copyright holder. To view a copy of this licence, visit http://creativecommons.org/licenses/by/4.0/. non-diabetic subjects [3]. DM has a significant burden on the economy, in both relations to the actual costs of health care treatment as well as to the expense of reduced production (indirectly) due to the mortality and morbidity linked with diabetes [4]. The costing of DM is mostly due to complications of the vascular system (micro and macro) like neuropathy, disease of the renal system, retinopathy, hypertension, infraction of myocardia, and disease of the coronary artery [3, 4].

There is a strong association between DM and CVD (disorders of cardiovascular). Among the patients of diabetes, CVD is mostly responsible for mortality. Throughout the USA, the CVD mortality rate for diabetic adults (with age more than 18), showed a rise in the risk of a heart attack and infraction of myocardia which is 1.8 percent larger than for those who have no DM identified 
[5, 6]. For both males and females, this elevated risk of CVD death is seen in diabetic people. The overall risk in diabetic patients for CVD mortality rates varies from 1-3 in males and 2-5 in females as in those lacking DM [7].

Controlling DM properly and managing it is important because the progression of the disease incidence and financial burden is continuing to increase. Since CVD is the more common cause of death and morbidity in DM patients, the main purpose of care for diabetic must be the enhancement of diabetic patients' cardiovascular risks. But the complicated and ongoing strength of the association between DM and CVD is a problem linked with the treatment of DM and incidents of CV (cardiovascular). In DM patients, especially those with type 2 $\mathrm{DM}$, the factors of risk of $\mathrm{CV}$ include dyslipidemia, hypertension, and obesity which are frequent. Furthermore, findings have shown that multiple causes, like neuropathy, dysfunction of endothelial, coagulation enhancement, and increase in stress of oxidation are frequently present in patients with diabetes which contributes to CVD development [5]. Taken together, elevated factors of risk of the cardiovascular system and clear physiological activities of diabetes mostly on the system of $\mathrm{CV}$ put patients with diabetes at greater risk for the presence of chronic heart failure, stroke, revascularization, increased risk of myocardial infarction, and other disorders of the cardiovascular system [8]. Due to the complexities of the DM-CVD and its processes, care needs to be optimized to maximize the CV results. This article discusses how DM can be associated with CVD and the latest strategies for treatment and possible work on the management of diabetes.

\section{Main text}

\section{Possible risk factors of diabetes Obesity}

Obesity or overweight is related to adipose tissue accumulation that to an extent has a deleterious effect on both the physical and psychological health [9]. Obesity is associated with many chronic diseases including hypertension, diabetes mellitus, dyslipidemia, osteoarticular disease, sleep apnea, and cerebrovascular and cardio diseases. Obesity is a major concern of health worldwide due to the current lifestyle of people and their connection with other chronic diseases [10]. The data of WHO (World Health Organization) indicated that the obesity prevalence around the globe was 10 percent in males and 14 percent in females. According to the information from NHANES (National Health and Nutrition Examination Survey), it was found that the obesity prevalence and overweight amplified from $55.9 \%$ to $64.5 \%$ from 1988-1994 and $22.9 \%$ to $30.5 \%$ from $1999-2000$ [10]. Body mass index is found to have a strong connection with the resistance of insulin and diabetes. The substances such as glycerol, non-esterified fatty acids, cytokines (interleukin (IL)-6, IL-1, leptin, fibrinogen, tumor necrosis factor-alpha (TNF), PAI-1, resistin MCP1 , angiotensin), hormones, proinflammatory markers which are involved in the growth of resistance of insulin, increase in obese patients. The pathogenesis of diabetes involves the impairment of beta-islet cells of the pancreas or resistance of insulin or both in severe diabetes [11]. The mechanisms of obesity being a factor of risk for diabetes are shown in Table 1 . The mechanism behind both diabetes mellitus and obesity is the resistance of insulin.

The sensitivity of insulin fluctuates throughout the life cycle naturally as noticed during pregnancy, puberty, and the aging process [11]. Additionally, lifestyle changes such as enhanced uptake of carbohydrates and raised physical exercise are also factors causing the sensitivity of insulin fluctuations [18]. The main and foremost substance affecting insulin resistance is a non-esterified fatty acid (NEFA). The increased level of NEFA is linked with the resistance of insulin both in diabetes 2 and obesity [17]. Insulin sensitivity is also affected by body fat distribution. There has always been entirely different insulin sensitivity in lean individuals as compared to those who are not lean due to body fat distribution differences. The more peripheral fat distribution, the more is the insulin sensitivity [11]. The adipose tissue distribution differences also explain the difference in metabolic effects of intra-abdominal fat and subcutaneous fats. It has been found that intra-abdominal fats have genes that are responsible for the secretion of specific types of proteins that are responsible for energy generation. The secretion of adiponectin is done by omental adipocyte and it has been observed that this secretion has a negative coassociation with increase in bodyweight. Thus, the NEFAs release may be influenced by the presence in different tissues [17]. Fat of intra-abdominal is more crucial in the resistance of insulin as it is more lipolytic and does not easily react to insulin activity of antilipolytic $[19,20]$. CVD is also interlinked with diabetes and obesity due to the association of inflammation (low grade) as shown in Fig. 1. The overexpression of cytokines like IL6, IL-1, leptin, PAI-1, resistin MCP-1, angiotensin, and TNF fibrinogen causes inflammation to increase and lipid to accumulate that in turn have a disastrous impact on vessels of blood and can ultimately cause endothelial dysfunction, cardiomyopathy, and myocardial infarction [12-16, 21]. These cytokines overexpression links the association of resistance of insulin and DM.

\section{Hypertension}

Hypertension is very common among diabetics and one of the highly prevalent diseases around the world. Sixty percent of diabetes 2 patients have hypertension in 
Table 1 Obesity as a factor of risk for diabetes

\begin{tabular}{lll}
\hline $\begin{array}{l}\text { S. } \\
\text { no. }\end{array}$ & $\begin{array}{l}\text { Proposed mechanisms of obesity being a risk factor for } \\
\text { diabetes }\end{array}$ & Result \\
\hline 1 & Overexpression of cytokines by adipose tissues [12] & $\begin{array}{l}\text {-Increased inflammation } \\
\text {-Lipid accumulation [13-16] }\end{array}$ \\
2 & An increased amount of C-reactive protein [16] & $\begin{array}{l}\text {-Impairs nitric oxide production and prostacyclin } \\
\text {-Increased uptake of LDL (low-density lipoprotein) [16] }\end{array}$ \\
3 & Decreased adiponectin production & Increased NEFA [17] \\
4 & Fat mass distribution & The more peripheral fat distribution, the more is the insulin sensitivity \\
& & {$[11]$}
\end{tabular}

adjunct $[22,23]$. The two conditions when coexists increase the chances of both complications, i.e., microvascular and macrovascular. Complications of macrovascular include infarction of myocardial and stroke whereas complication of microvascular includes retinopathy and nephropathy [24].

The onset of hypertension in diabetics relies on diabetes type. In diabetes (type 1), hypertension onset appears after years of diagnosis and majorly have diabetic nephropathy [23]. Hypertension can be present before the glucose level increases in the body in diabetes 2 patients [25]. The development of diabetic nephropathy is closely related to patients with diabetes and hypertension [26]. Hyperglycemia stimulates the renal cells and as a result cytokines, humoral mediators, and growth factors are produced. This production causes an alteration in the structure of glomeruli of a diabetic patient, an increase in the matrix of extracellular collagen deposition, and a rise in glomerular basement membrane permeability [27]. The structural changes result in microalbuminuria and chronic generation of RAAS (renin-angiotensin system) which progresses into hypertension [28].
Dm is involved with various mechanisms pathophysiologically as shown in Fig. 2. Diabetes and hypertension have interlinked pathways like the stress of oxidation, renin-angiotensin-aldosterone system (RAAS), resistance of insulin, (SNS) sympathetic nervous system, PPARs, and adipokines. These pathways are interconnected and interact with each other and may even result in a vicious cycle $[29,30]$. The development of proteinuria in diabetic patients leads to hyperlipidemia which increases the chances of CVD in these patients.

\section{Dyslipidemia}

Diabetic patients are at an increased prevalence of dyslipidemia development [31]. The proposed underlying pattern observed in the development of dyslipidemia in diabetic patients is an increased level of triglycerides, LDL (low-density lipoprotein), and reduced level of HDL-C (high-density lipoprotein cholesterol) [32]. One of the prominent features of dyslipidemia in diabetes is an elevated number of LDL particles from either LDL-P or ApoB. There is also an associated high risk of nephropathy as LDL particles tend to be more atherogenic

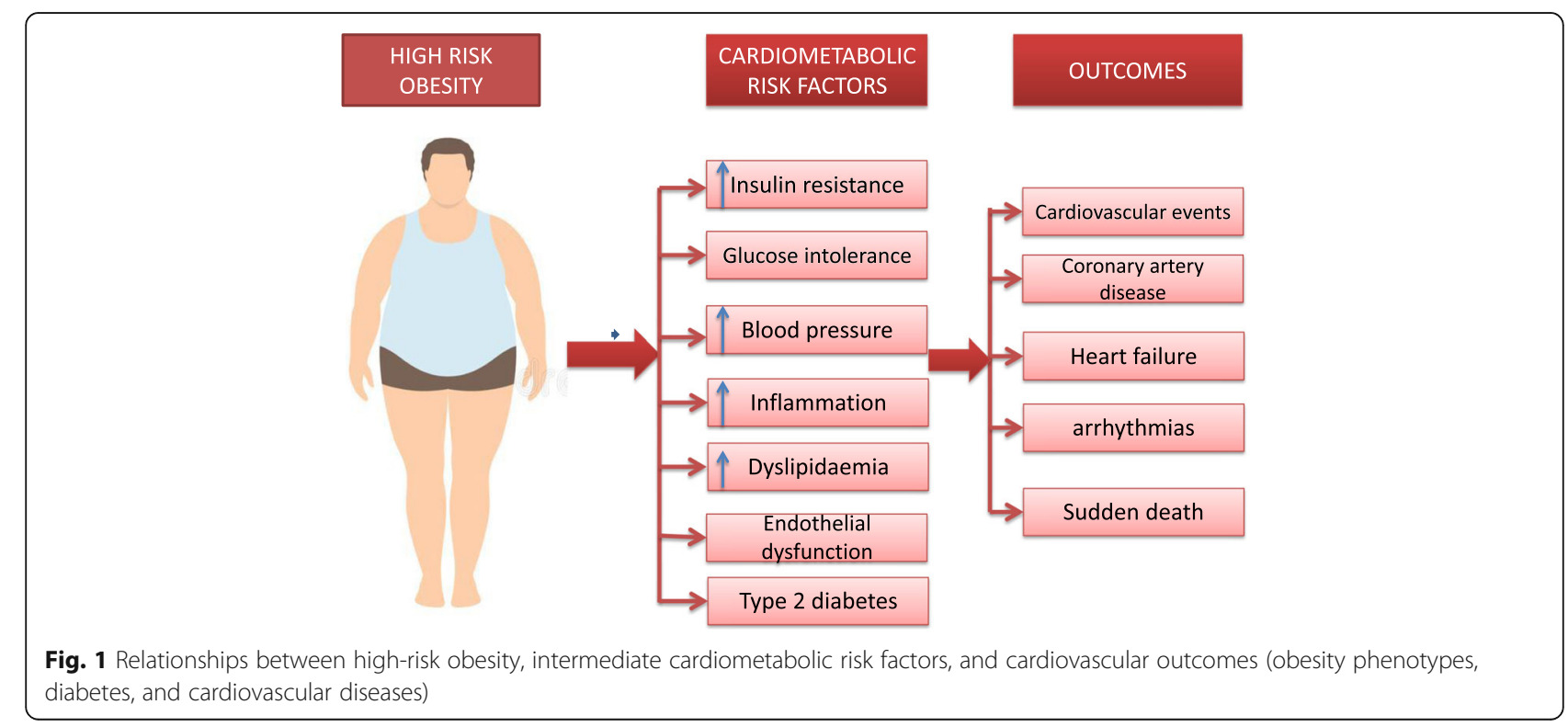




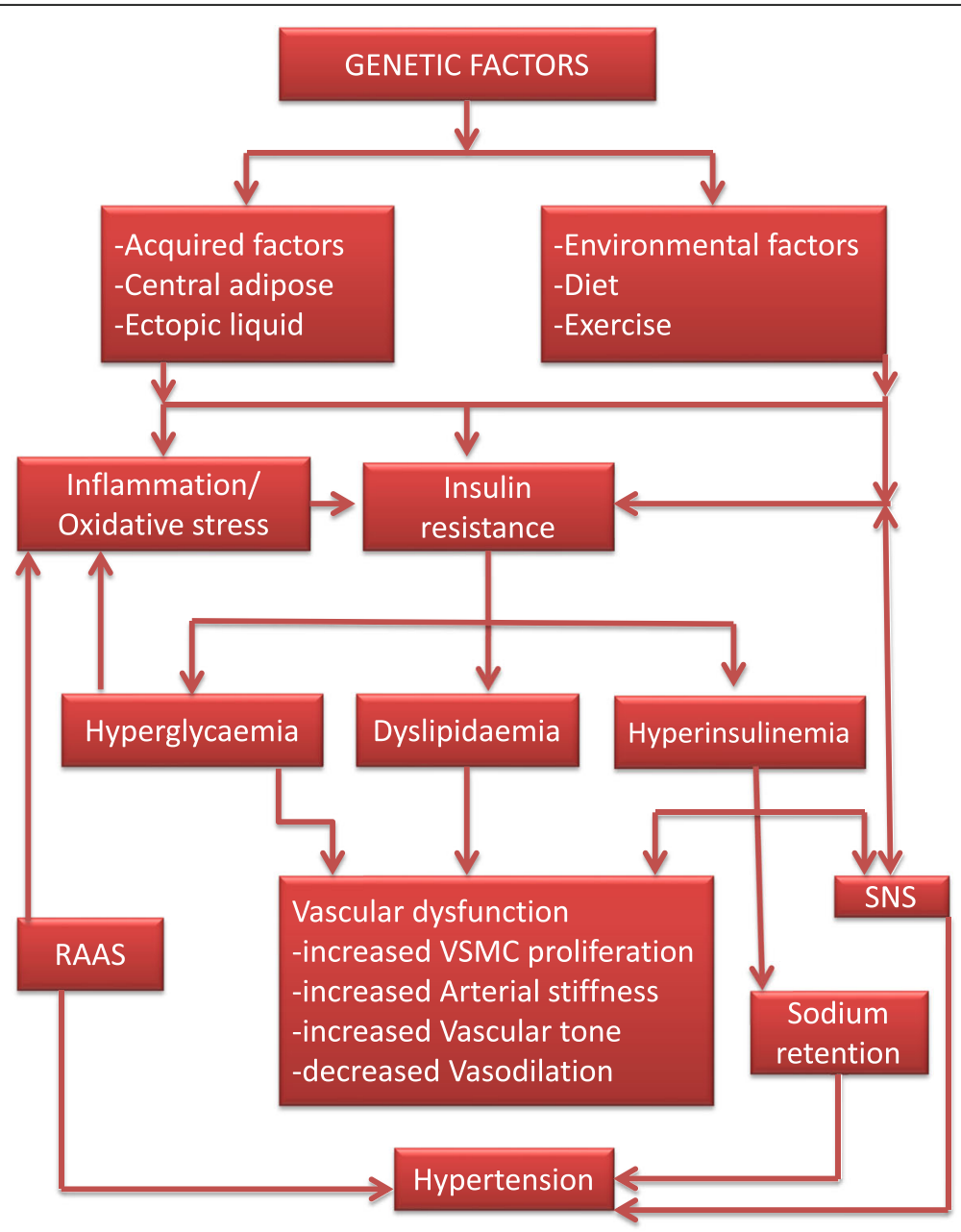

Fig. 2 Summary of pathophysiologic mechanisms in the development of hypertension in diabetes mellitus (VSMC—vascular smooth muscle cell)

[33]. Lipid abnormalities in diabetic patients are shown in Table 2.

The main underlying mechanism for the development of dyslipidemia in diabetic patients is insulin resistance as shown in Fig. 3 [38]. Adipose tissue release of free fatty acids increases in the case of peripheral insulin resistance, which are further entrapped by the liver, in turn, leads to the elevated synthesis of TG (triglycerides) by the hepatic cells. There is an elevation in ApoB secretion and synthesis of triglyceride-rich VLDL (very low-density lipoprotein) due to the hepatic stimulation caused by triglyceride synthesis [39]. The highly loaded VLDL with triglycerides enriches $\mathrm{HDL}$ and LDL and makes them richer in cholesterol through the work of cholesterol ester transfer protein [40]. The triglyceride-rich LDL molecules aid in the synthesis of small dense LDL as it gets hydrolyzed by lipoprotein lipase or hepatic lipase. This underlying pathophysiology of dyslipidemia increases the CVD

Table 2 Lipid abnormalities in diabetic patients

\begin{tabular}{lll}
\hline $\begin{array}{l}\text { S. } \\
\text { no. }\end{array}$ & Type of diabetes & Lipid profile \\
\hline 1 & $\begin{array}{l}\text { Type } 1 \text { diabetes } \\
\text { mellitus }\end{array}$ & Similar to the general population if glycemic control is good [34] \\
2 & $\begin{array}{l}\text { Type } 2 \text { diabetes } \\
\text { mellitus }\end{array}$ & $\begin{array}{l}\text { Apolipoprotein B, particle number of LDL, LDL (small dense) increase with LDL-C. HDL-C decreases. Non-HDL-C, IDL, } \\
\text { VLDL, triglycerides increase [35-37] }\end{array}$ \\
$\begin{array}{l}\text { Poor glycemic } \\
\text { control }\end{array}$ & Particle number and LDL (small dense) increase. HDL-C decreases and IDL, VLDL, and triglycerides increase [36]
\end{tabular}



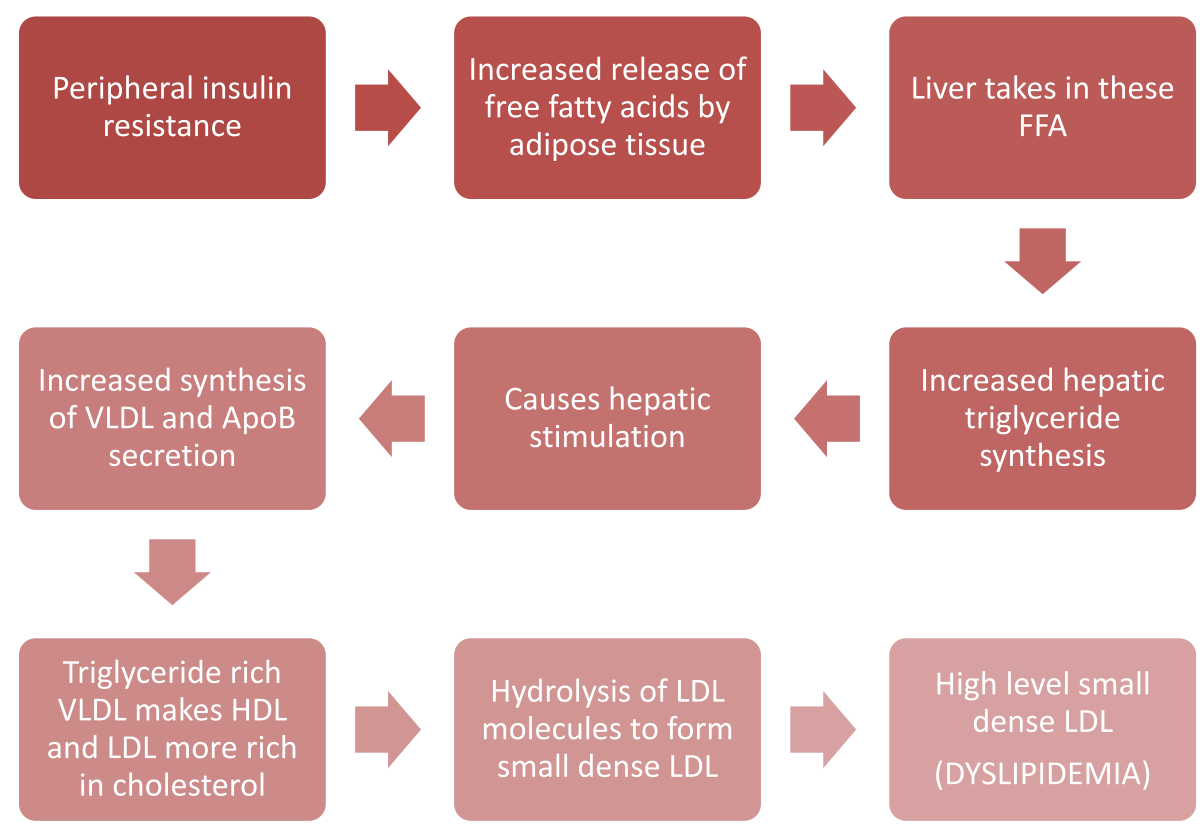

Fig. 3 Mechanism of dyslipidemia in a diabetic patient

prevalence in patients of diabetes. Modern therapy of diabetic patients necessitates lipids to be treated to decrease the risk of cardiovascular diseases.

\section{Cardiomyopathy}

The development of cardiomyopathy is a direct consequence of DM. The pathophysiological pathways of cardiomyopathy of diabetes are shown in Fig. 4. The diabetic cardiomyopathy shows heart changes functionally and the left ventricle changes structurally [41]. The diabetic patient shows to have increased left ventricle mass as compared to non-diabetics $[42,43]$. It may be proposed that the increased cardiac mass in diabetics is due to the increased release of cytokines having hypertrophic effects on cardiac cells like resistin and leptin from the adipocytes [44, 45]. Patients with diabetes mellitus are also found to have slightly decreased diastolic function in comparison to non-diabetic [46-48]. Mechanisms contributing to diabetic dysfunction of the cardiac system are shown in Table 3. One proposed mechanism for the same could be the increased triglyceride content in the cardiomyocytes due to the elevated synthesis of

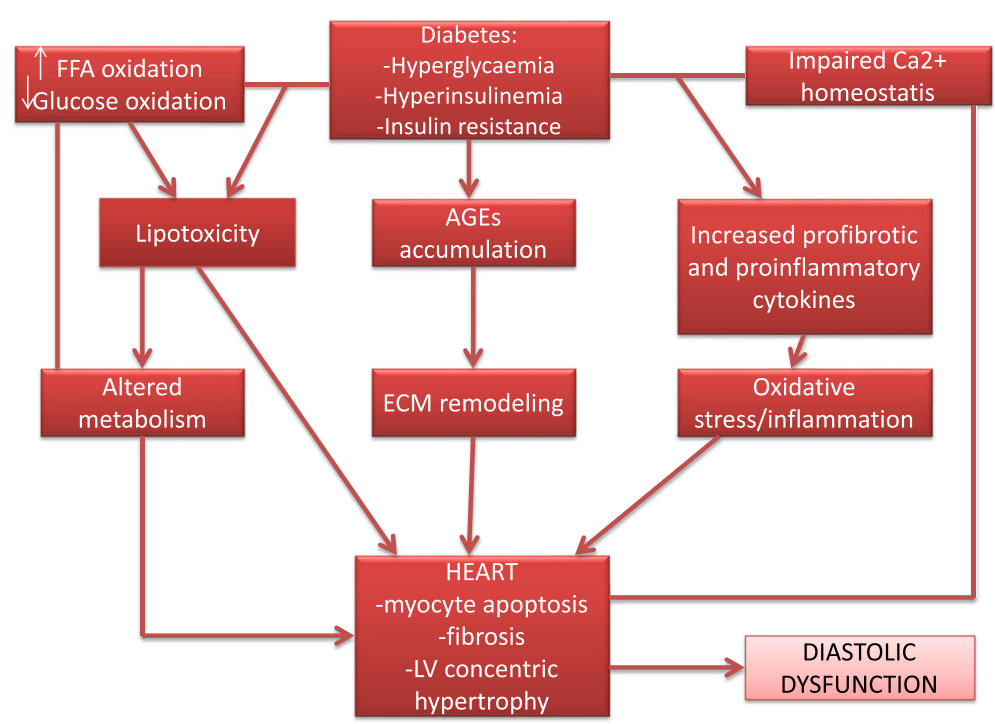

Fig. 4 Mechanism of the pathophysiology of cardiomyopathy of diabetes 
Table 3 Mechanisms contributing to diabetic dysfunction of the cardiac system

\begin{tabular}{llll}
\hline S. & Dysfunction of the cardiac system & & Contractile reserve \\
\cline { 2 - 4 } & Diastolic dysfunction & Systolic dysfunction & Mitochondrial dysfunction \\
\hline 1 & Cardiac steatosis & AGE formation & Homeostasis of calcium is altered
\end{tabular}

triglycerides in diabetics [49]. As a response to triglyceride accumulation in the myocardium, there is a chance of lipotoxicity and the calcium hemostasis also is altered. Both of these factors harm the diastolic function [5052]. It has also been stated that $40-70 \%$ of diabetics with no indication of overt CAD (coronary artery disease) are diagnosed with diastolic function. Subtle alterations have also been found in systolic functioning in diabetic patients using Doppler strain analysis of systolic velocity and tissue Doppler imaging [53-57]. The systolic dysfunction can be due to the impaired contractile reserve and impaired sympathetic innervation of the myocardium [58]. Interstitial fibrosis accompanying elevated collagen deposition is also seen in diabetic patients and has a negative impact on cardiac function [59]. The mechanisms following the diminished systolic and diastolic functions of the heart also increase the risk of having heart failures in diabetic patients $[60,61]$. The chances of heart failure in a diabetic are very much that is $16-31 \%$ as compared to the general population that accounts for only 4-6\% [62].

\section{Cardiovascular autonomic neuropathy}

Cardiovascular autonomic neuropathy (CAN) has been commonly noticed in diabetic patients [63]. It is one of the most overlooked complications in diabetic patients [64-66]. CAN involves the harm to fibers of the autonomic nerve. These autonomic fibers innervate the vessels of blood and the heart and the result is abnormalities in vascular dynamics and heart rate control [67]. The chances for a diabetic patient to have CAN persist from 2.5 to $90 \%$ and the risk raises with diabetes duration, age, and improper glycemic control [68]. An inter-link among inflammation, imbalance of autonomic, and CVD has been demonstrated in recent studies as increased inflammatory markers (IL 1 and CRP) are involved in dysregulation of ANS (autonomic nervous system) with elevated activity of the sympathetic system [69, 70]. As the ANS is involved in activity modulation of the sinus node (heart rate), end-diastolic and systolic volume, the resistance of systemic vascular, the dysregulation of the autonomic nervous system may result in left ventricular hypertrophy, arterial stiffness, and dysfunction of diastolic of the ventricle [71]. Clinical manifestations of CAN be named as follows: postural hypotension, abnormal coronary vasomotor regulation, tachycardia, the elevation of QT interval, increased danger of renal disease, exercise intolerance, death, and stroke [72]. CAN tends to be a robust presence of cardiovascular disease in both type 1 and type 2 diabetes. Diabetics with CAN have a mortality rate of 5 years ranging from $16-53 \%$ and entirely depend on the severity [73]. According to a study conducted, a complex interaction between duration of the disease, neuronal death relating to age, a diastolic and systolic pressure of blood, and control of glycemic results in diabetes-related CAN [66]. The main culprit is thought to be hyperglycemia that is involved in the stimulation of a cascade of multiple complex pathways and mechanisms which result in oxidative stress induction and production of toxic glycosylation substances that ultimately lead to neuronal abnormalities and death. With age, the diabetics increase the chance of development of CVD and CAN [74].

\section{Glycation}

Advanced glycation-a biochemical process that tends to accelerate in diabetes due to elevated oxidative stress and chronic hyperglycemia and is found to play a central role in diabetes. Generation of the advanced glycated end products (AGEs) that are a heterogeneous group of chemical moieties takes place due to advanced glycation. This production of AGEs is a result of a non-enzymatic reaction involving vital intermediates such as methylglyoxal and a reaction with the glucose that interacts with lipids, nucleic acids, and proteins. AGEs produce deleterious results in diabetic patients. AGEs can alter the structure and function of the vasculature as it promotes vascular stiffness by directly inducing the crosslinking of proteins such as collagen that are long lived. AGEs also enhance the oxidative stress and release of key pro-sclerotic and proinflammatory cytokines by interacting with certain receptors such as RAGE (receptor for AGE).

AGEs are heterogeneous complex moieties that are formed via a non-enzymatic reaction between glucose and other reducing sugars with amine residues on proteins, nucleic acids, or lipids. N (carboxymethyl) lysine and pentosidine are some of the prominent AGEs found in humans $[75,76]$. AGEs can be produced by exogenous sources also apart from endogenous production. Exogenous sources include tobacco smoke and diet [7780]. Prolonged heating can accelerate the production of glycol oxidation and lipo-oxidation compounds. A major part of the ingested AGEs is absorbed with food. AGEs 
often concentrate intracellularly as they are generated from dicarbonyl precursors derived from glucose [81]. The intracellular AGEs act as stimuli for intracellular signaling pathways activation as well as are also involved in the modification of intracellular protein function [82].

Accumulation of AGEs in organs damaged due to diabetes increases as a result of hyperglycemia. AGEs cause the crosslinking of intermolecular collagen that leads to diminished myocardial and arterial function. It also increases vascular stiffness. All these phenomena can be used to partly explain the elevation in systolic hypertension and diastolic dysfunction noted in diabetic patients. Some of the diabetic damaged sites of accumulation of AGEs are retina, kidney, and atherosclerosis plaques as shown in Table 4 [91, 95, 96].

\section{Role of genetics between CVS disorders and DM}

The close association of DM and CVD and their factors give rise to the theory that both the conditions follow common genetic, epigenetic, and environmental factors. Many SNP (single nucleotide polymorphism) are found to be associated with CVD and DM [97]. Postulates proposed by "stern" also shows that both the disease occur independently but share a common soil [98]. Recently, many noncoding RNA appeared as indispensable factors involved in the pathophysiology of both the conditions which underlie common epigenetic links between these two $[99,100]$.

Monogenic factors CVD and DM are polygenic but Mendelian forms have been described for both the conditions where a single gene mutation initiates the disease
$[101,102]$. However, all gene mutation does not predispose to both the disease. A recent study shows the protective role of Apo B gene mutation in DM which is the most commonly studied gene in familial hypercholesterolemia [103].

Genetic polymorphism Many loci are associated with both conditions. Genome-wide association studies (GWAS) in combination with large cohort studies support to find of the common loci's. As of now, at least 83 loci are found to be associated with DM and more than 30 loci with CVD [104, 105]. Some genes are shown in Tables 5 and 6 whose variants are involved in both the disease.

\section{Treatment}

Since CVD is perhaps the common cause of death and disease among diabetic patients, it is vital to have adequate therapy to minimize the chances for events of the cardiovascular system in patients with diabetes, especially with CHF (chronic heart failure), stroke, and infarction of myocardia. The enhanced chance of cardiovascular complications in patients is due to the factors like dysfunction of the autonomous system, dyslipidemia, hypertension, and obesity. Treatment aimed at improving these health risks can boost $\mathrm{CV}$ results, though this can be difficult to accomplish. Investigation on how the $\mathrm{CV}$ risk level of people with diabetes is affected by these various risk factors may be vague and often conflicting. This section aims to include the current recommendations on several treatment strategies for the same. Treatment

Table 4 Effect of AGEs accumulation on target organs

\begin{tabular}{|c|c|c|}
\hline Complication & Target organ & AGEs role in preclinical studies \\
\hline Diabetic nephropathy & Kidney & $\begin{array}{l}\text {-Glomerular membrane thickening } \\
\text {-Mesangial expansion } \\
\text {-Glomerulerosis } \\
\text {-Tubulointerstitial fibrosis }[83,84]\end{array}$ \\
\hline Diabetic ocular diseases & $\begin{array}{l}\text { Eyes-retinal blood } \\
\text { vessels }[85,86]\end{array}$ & $\begin{array}{l}\text {-Basement membrane thickening } \\
\text {-Breakdown of inner blood-retinal barrier }[87,88]\end{array}$ \\
\hline Diabetic peripheral neuropathy & Peripheral nerves & $\begin{array}{l}\text {-Link microangiopathy and neuropathy } \\
\text {-Localization of RAGE, IL-6, CML, and NF-kappaB to endoneurial vessels, perineur- } \\
\text { ium, and epineurial vessels } \\
\text {-Reduce sensorimotor conduction velocity } \\
\text {-Decrease blood flow to peripheral nerves [89] }\end{array}$ \\
\hline Atherosclerotic disease & & $\begin{array}{l}\text {-Elevates endothelial dysfunction } \\
\text {-Increase vascular LDL levels by decreasing LDL uptake } \\
\text {-Promote plaque destabilization } \\
\text {-Dysfunctioning of vascular repair in response to injury [90] } \\
\text {-Quench nitric oxide and impair LDL removal } \\
\text {-Elevated localization of AGE-LDL in vessels and elevated generation of foam } \\
\text { cells thus accelerate atheroma formation [91] }\end{array}$ \\
\hline $\begin{array}{l}\text { Diabetic cardiomyopathy and peripheral } \\
\text { arterial disease (PAD) }\end{array}$ & Cardiovascular system & $\begin{array}{l}\text {-Crosslinking of collagen [92] } \\
\text {-Carotid intima-media wall thickening } \\
\text {-Arterial stiffness }[93,94] \\
\text {-Increased levels of malondialdehyde and pentosidine }\end{array}$ \\
\hline
\end{tabular}


Table 5 Genes whose variants increase the risk of DM and CVD

\begin{tabular}{ll}
\hline Gene & Protein function \\
\hline TCF7L2 & Transcription factor 7 like $2[106,107]$ \\
PHACTR1 & Phosphatase and actin regulator 1. It involves the reorganization of the actin [108] \\
HMGA1 & High-mobility group A1. Involved in glucose metabolism and cell growth differentiation [109, 110] \\
Paraoxonase & Protects from lipid oxidation [111, 112] \\
Adiponectin & Adipokine with anti-atherogenic and anti-inflammatory effects [113] \\
CDKN2A/2B & Cyclin-dependent kinase inhibitor. Cell cycle regulation [108] \\
\hline
\end{tabular}

approaches can be divided into lifestyle modifications and pharmacological interventions.

\section{Pharmacological interventions}

Obesity Obesity is one of the major factors of risk which raises the prevalence of CVD-related mortality and morbidity in DM patients. So many clinical guidelines suggest reducing the weight of DM patients to reduce CVD risk profiles. The syndrome of metabolic and resistance of insulin is found to play a prominent role in cardiovascular mortality and morbidity [114, 115]. Type 2 DM along with visceral adiposity and an excess of ectopic fat clearly show high risks of cardiovascular morbidity and mortality [116]. Individuals with high visceral adipose tissue - this is the condition where fat deposition occurs at lean tissues like the liver, the skeletal muscle, and the heart are at high risk. The simultaneous presence of obesity and DM should further increase the risk of cardiovascular outcomes [117].

According to the trial of SCOUT, the modest loss of weight can enhance rates of mortality of $\mathrm{CV}$ in DM patients. Look AHEAD trial did not find any reduction in the chances of $\mathrm{CV}$ events like MI, stroke after weight loss in DM patients after 9.6 years of follow up [118, 119].

Various pharmacological drugs are found to be effective in weight loss which reduces the CVD risk [120$124]$. Some drugs which are prescribed to control glucose level in DM patients are also effective in weight loss; GLP-1 (glucagon-like peptide-1) receptor agonists and SGLT2 (sodium-glucose co-transporter 2) inhibitors indicated efficacy towards weight loss in diabetes patients $[125,126]$.

A meta-analysis stated that the inhibitors of SGLT 2 decreased the chance of hospitalization in heart attack and cardiovascular death by $23 \%$ in patients with or without a history of heart attack and in patients with or without atherosclerotic CVD [127]. Another meta-analysis showed a $13 \%$ risk reduction in cardiovascular deaths in DM patients using GLP-1 receptor agonists [128].

Surgical interventions are more effective for sustained weight loss than standard approaches [129, 130]. The STAMPEDE clinical trial (Surgical Treatment and Medications Potentially Eradicate Diabetes Efficiently), demonstrated that weight loss surgeries are more effective than intensive medical therapy in terms of weight reduction, glycemic control and in reducing the dose of lipidlowering medications and improving the quality of life during the 5 years follow-up study.

Two main mechanisms are involved in weight loss surgeries:

1. Restrictive surgeries

2. Mal-absorptive surgeries

Restrictive surgeries restrict the intake of food by reducing the size of the stomach and mal-absorption surgeries reduce the amount of absorption by bypassing the different parts of the small intestine. Sleeve gastrectomy is the most famous restrictive type which reduces weight by reduced meal volume and reduced appetite. Both types of surgeries restrictive and bypass reduce visceral fat and reduce more subcutaneous fat levels [131-133].

In a study of Swedish obese patients, weight loss surgery leads to a $30 \%$ reduction in cardiovascular events and a $50 \%$ reduction in cardiovascular deaths in obese patients in comparison to those who received standard care after 15 years of follow-up [134]. A retrospective study on 20,235 surgical and non-surgical treated patients demonstrated a reduction in incidences of coronary artery disease in patients who are treated with weight-loss surgeries [135]. In one more retrospective study, 14 patients with heart failure and reduced ejection capability treated with weight loss surgeries, and a significant reduction in BMI and improvement in left

Table 6 Genes whose variants decrease the risk of DM and CVD

\begin{tabular}{ll}
\hline Gene & Protein function \\
\hline PCSK9 & Proprotein convertase subtilisin/Kexin type 9. Metabolism of plasma cholesterol [108] \\
CELSR2-PSRC1-SORT1 & CELSR2 belongs to the cadherin superfamily; carry out contact mediated-communication [108] \\
\hline
\end{tabular}


ventricular ejection was seen at 6 months [136]. Similarly, another retrospective study on 12 patients with a heart attack and low ventricular ejection who underwent weight-loss surgery showed significant improvement in ventricular ejection following surgery [137].

Treatment of obesity and maintenance of BMI could significantly improve the condition and could reduce the cardiovascular risk factors in DM patients.

Hypertension Around 50-80\% of type 2 diabetes mellitus patients suffer from coexisting hypertension. The existence of hypertension in diabetic patients worsens the clinical outcomes of both macrovascular and microvascular diabetes. Their coexistence is the leading factor for atherosclerosis and linked complications [138]. The pharmacological treatment for hypertension management is utilization of inhibitors of ACE (angiotensinconverting enzyme), blockers of the receptor of the angiotensin receptor, diuretics, blockers of the channel of calcium which reduces blood pressure by blocking various receptors and channels that contribute to elevated blood pressure [139-142].

There have been many studies that evaluated high blood pressure (BP) role in DM patients on CV outcomes. The UKPDS 38 trial evaluated the significance of $\mathrm{BP}$ in DM patients on macrovascular and microvascular complications. The patients were randomized into a more tightly controlled BP group $(<150 / 85)$ and a less tightly controlled BP group $(<180 / 105)$. After 9 years of the follow-up period, there was a significant reduction found in BP of the tightly controlled group (144/82 $\mathrm{mmHg}$ versus $154 / 87 \mathrm{mmHg}$ ) in comparison to a less tightly controlled group. Also, a $34 \%$ reduction in macrovascular complications was seen in the tightly controlled BP group and a 37\% reduction in microvascular disease in comparison to the less tightly controlled group [143].

Most of the studies showed that lowering BP could improve $\mathrm{CV}$ complications in $\mathrm{DM}$ patients, the ACCORD-BP trial investigated the effect of tight $\mathrm{BP}$ control (systolic BP $<120 \mathrm{mmHg}$ ) to the standard BP control (systolic BP $<140 \mathrm{mmHg}$ ) on the risk of fatal or non-fatal major $\mathrm{CV}$ events in DM patients. After 4.7 years of the follow-up period, the tight BP control group does not show any significant reduction in risks of fatal and non-fatal major $\mathrm{CV}$ outcomes in comparison to the standard BP control group. Also, the tight BP control group showed more chances of adverse events [144].

Dyslipidemia Dyslipidemia is very prevalent in DM patients and an important risk factor for CVD [145]. Improvement in the profile of lipid, glycemic control, and resistance of insulin is observed in patients with a 5\% reduction in their body weight [146]. Weight loss improves blood pressure, reduces the level of triglycerides, and elevates HDL-C levels [147]. Although the loss of weight has indicated to enhance factors of multiple risks like blood pressure and hemoglobin $\mathrm{A} 1 \mathrm{C}$, it did not show any significant improvement in events of cardiovascular in the Look AHEAD study [119], indicating a necessity for pharmacotherapy with simultaneous lifestyle modification for the treatment of diabetic dyslipidemia [148].

Many pharmacological therapies are currently available including statins, niacin, fatty acids of omega-3, sequestrants of bile acid, inhibitors of absorption of cholesterol, and fibrates [149]. These drugs adopting different mechanisms of action have a crucial part in the treatment of diabetic dyslipidemia.

The Collaborative Atorvastatin Diabetes Study (CARDS) study was carried out in T2 diabetes mellitus patients to evaluate the effect of statin therapy. Patients were treated with $10 \mathrm{mg} / \mathrm{d}$ atorvastatin and the controlled group received a placebo. After 3.9 years of the follow-up period, a $26 \%$ reduction in total cholesterol level, and a $40 \%$ reduction in LDL-c was found. Also, a 37\% reduction in CV events and a $48 \%$ reduction in stroke were found in patients treated with statin therapy in comparison to the controlled groups. The CARDS study was stopped in between due to the significant results demonstrated in favor of statin therapy [150].

After significant results of the CARDS study, the TNT trial was carried out, high dose versus low dose statin therapy in T2 DM patients to examine nonfatal MI, CAD mortality, and fatal non-fatal stroke risk. Patients were randomized to receive high dose $(80 \mathrm{mg} / \mathrm{d})$ and low dose $(10 \mathrm{mg} / \mathrm{d})$ statin therapy. After a follow-up period of 4.9 years, high dose statin group received a greater reduction in LDL-c $(77 \mathrm{mg} /$ $\mathrm{dl}$ vs $101 \mathrm{mg} / \mathrm{dl}$ ) and a greater reduction in non-fatal MI, CAD mortality, and fatal nonfatal stroke risk $(8.7 \%$ vs $10.9 \%)$ in comparison to low dose statin group but it was observed that high dose statin group also shows high chances of adverse events [151].

The HDL Atherosclerosis Treatment Study (HATS) trial is one of the first trials which examined the increased level of HDL cholesterol by niacin therapy and its effect on CV outcomes. Adults were randomized to niacin therapy (16\% with DM) and after a follow-up period of 38 months, a significant increase in HDL level was found in niacin therapy patients and patients with T2 DM had 13\% fewer chances of CV outcomes [152].

CAN Patients with diabetes mellitus and CAN are at an elevated risk of cardiovascular associated mortality and 
morbidity as it is a very common complication of diabetes. The autonomic dysfunction that occurs in diabetic patients is linked with an elevated risk of cardiac arrhythmia and sudden deaths. Other serious CV problems include myocardial ischemia, perioperative, and intraoperative CV instability, stroke, diabetic cardiomyopathy. Common manifestations of CAN include hypotension, tachycardia, heart rate variability, and irregular blood pressure [73].

The complications and the pathogenesis of CAN can be reduced by the treatment of autonomic dysfunction [73]. According to many studies, it has been observed that strict glycemic control can be beneficial in reducing the occurrence of CAN in a diabetic patient. An example of the mentioned statement is that reports by DCCT mentioning that patients measured for Hbalc and found to have enhanced glycemic control are safer and have a lower risk to develop autonomic dysfunction as measured by CAN index [153]. Apart from glycemic control, many studies including the Steno- 2 study states that by improving glucose control and cardiovascular risk factors, the incidence of CAN can be reduced in diabetic patients [154]. Pharmacotherapy agents include angiotensin receptor blockers, ACE inhibitors, and aldose reductase inhibitors that help in decelerating the progression of cardiovascular autonomic neuropathy [155]. The best pharmacological treatment is yet to be found by conducting various studies and researches.

Diabetic cardiomyopathy In cardiac myopathy, heart muscles become enlarged, thick, and rigid [156]. The prevalence of cardiac myopathy also increases along with the severity of DM. Diabetic cardiomyopathy represents various conditions such as dysfunction of diastolic, remodeling dysfunctionally, and myocardial fibrosis [41]. Some treatment therapies are shown in Table 7 [157].

Adjuvant pharmacological interventions Phytoconstituents also play a significant role in the treatment of various chronic diseases such as CVD, DM, and certain types of cancer. Overproduction of oxygen free radicals in the human body and an increase in oxidative stress is involved in the pathogenesis of many chronic diseases. Chronic inflammation is also a significant factor that is involved in the pathogenesis of CVD and DM and cancers [158-160]. So, the protective role of phytoconstituents is due to their antioxidant and anti-inflammatory properties. Phytoconstituents like curcumin, anthocyanins show anti-inflammatory properties by reducing the production of prostaglandins and by inhibiting nuclear factor $\mathrm{K}$-B activity $[161,162]$.

Obesity is one of the significant risk factors in CVD and DM could be treated by phytoconstituents. Antioxidant defenses (endogenous antioxidant) activity is low in obese parts in comparison to their normal-weight counterparts [163]. Fruits and plants which have a high saturation of antioxidant phytoconstituents show anti-obesity action. Due to the high level of flavanones, citrus fruits show inhibitory activity on pancreatic lipase and $\alpha$ glucosidase in vitro [164]. Phytochemicals like proanthocyanidins and anthocyanins present in Aristotelia chilensis and Vaccinium floribundum limit the adipogenesis and inflammatory pathways in vitro [165].

Antioxidant compounds including phenol carboxylic acids, ascorbic acid, flavonoids, iridoids which are present in Plantago maxima extract, could reverse dietinduced obesity. Grape products rich in polyphenols could reduce the obesity-mediated chronic inflammation

Table 7 Treatment strategies of diabetic cardiomyopathy

\begin{tabular}{ll}
\hline Conventional therapies & Inhibitors of angiotensin-converting enzyme \\
& Therapies of lowering lipid \\
& Blockers of calcium channel \\
& Beta-blockers \\
Thiazolidinediones & Incretin based therapy \\
Novel therapies & Glycemic control \\
& Dysregulated microRNAs \\
& Gene therapy \\
Inhibition of mitogen activity of pathway of protein kinase & Signaling of protein kinase C \\
& Signaling of cardiac phosphoinositide 3-kinase \\
& Exercise \\
& Supplementation of coenzyme Q10 \\
\hline
\end{tabular}


through various mechanisms such as blocking proinflammatory cytokines, by activating transcription factors that antagonize chronic inflammation $[166,167]$. Resveratrol shows in vitro anti-obesity action by inhibiting adipogenesis. Curcumin also reduced obesity and related adverse effects of obesity. Allicin also showed antiadipogenesis activities $[168,169]$.

\section{Lifestyle modifications}

Apart from pharmacological interventions, complications of DM and CV disorders can be managed by modifications in the lifestyle.

Current treatment recommendations encourage obese DM patients to reduce their weight and in turn reduce risk factors for CVD. These recommendations are divided into "high," "moderate," and "low" based on the different methodologies of scientific and clinical practice. There is a "moderate" amount of shreds of evidence which suggest a $5 \%$ loss in weight by lifestyle intervention leads to a subsequent increase in HDL cholesterol, a decrease in triglyceride level, and reduces in the latest prescribed lipid slowing drugs [120-122]. The diabetes prevention program (DPP) and Finnish diabetes prevention data stated that lifestyle changes and weight loss prevents pre-diabetic patients from diabetes. As in general, lifestyle interventions (physical activity and diet) leads to excess loss of VAT and ectopic fat which subsequently decreases CV risk profile [123, 124, 170].

The lifestyle changes and management significantly assist in lowering blood pressure that is in controlling hypertension. The lifestyle modifications needed are caloric restrictions, reduction of sodium intake to a maximum of $2300 \mathrm{mg} /$ day, increasing fruits and vegetable consumption, and restricting alcohol consumption. Other lifestyle changes needed to control hypertension includes increased physical activity, smoking cessation, and reducing sedentary time. Lifestyle changes have been found to show a role in lowering blood pressure enhances metabolism and vascular system and also plays a synergistic role with antihypertensive medications. The treatment options or the ways to control and reduce the complications of the coexisting diseases with hypertension are lifestyle management, sodium reduction, physical activity, weight loss, sleep apnea treatment as shown in Table 8.

For managing dyslipidemia, non-pharmacological therapy or lifestyle modifications consist of nutrition, physical exertion, and loss of weight. Intake of plant stanols/ steroids, n-3 fatty acids, and viscous fiber (legumes, oats, citrus) should be increased and the consumption of saturated and trans-fatty acids should be decreased. Agents like peanuts, tree nuts, and grains should be consumed as they help in lowering cholesterol and blood pressure as they are a good source of unsaturated fat. Improvement in the profile of lipid, glycemic control, and resistance of insulin is observed in patients with a 5\% reduction in their body weight. Weight loss improves blood pressure, reduces the level of triglycerides, and elevates HDL-C levels [148, 180, 181].

\section{Interplay between lifestyle modifications and} genetics Various investigations involving epidemiology have suggested that the effect of various T2DM linked loci can be reduced by upgrading lifestyle and dietary patterns. The variant of PPARy that is Ala 12 is linked with enhancing the sensitivity of insulin. It has been found that the Ala 12 variant is more receptive to unsaturated fat than saturated fat. On the other hand, the Pro12 variant of PPARy shows more sensitivity to the damaging effects of malformed homeostasis of glucose and saturated fat. There is evidence of a potential interaction between the TCF7L2 risk variant and lifestyle modifications such as MNT, physical activity, and

Table 8 Treatment options for hypertension associated with diabetes

\begin{tabular}{|c|c|c|c|}
\hline $\begin{array}{l}\text { S. } \\
\text { no. }\end{array}$ & Treatment & Steps & Impact \\
\hline 1 & $\begin{array}{l}\text { Lifestyle } \\
\text { management }[138, \\
171]\end{array}$ & $\begin{array}{l}\text {-Caloric restrictions } \\
\text {-Sodium intake restrictions (2300 mg/day) } \\
\text {-Increase fruits and vegetable consumption } \\
\text {-Restricting alcohol consumption } \\
\text {-Reduce sedentary time } \\
\text {-Smoking cessation } \\
\text {-Increase physical activity [172-174] }\end{array}$ & $\begin{array}{l}\text {-Lowers blood pressure } \\
\text {-Synergistic for antihypertensive medications } \\
\text {-Enhances metabolism and vascular system }\end{array}$ \\
\hline 2 & Reduced sodium & $\begin{array}{l}\text {-Reduction of sodium intake per day. in a clinical trial, the sodium intake } \\
\text { was reduced from } 4600 \mathrm{mg} \text { to } 2300 \mathrm{mg} \text { [175] }\end{array}$ & $\begin{array}{l}\text {-Reduced pressure of blood (systolic approx. } 5 \\
\mathrm{mmHg} \text { and } 2-3 \mathrm{mmHg} \text { diastolic). }\end{array}$ \\
\hline 3 & Physical activity & $\begin{array}{l}\text {-30-45 min of brisk walking } \\
\text {-Regular exercise } \\
\text {-Type and intensity of exercise should be preferred according to patient } \\
\text { functional statu s[176, 177]. }\end{array}$ & Reduced blood pressure \\
\hline 4 & Weight loss & $\begin{array}{l}\text { Approximately } 1 \mathrm{mmHg} \text { of reduction in blood pressure can be achieved } \\
\text { by losing } 1 \mathrm{~kg} \text { of weight [178] }\end{array}$ & Reduced blood pressure \\
\hline 5 & Sleep apnea & Treat obstructive sleep apnea [179] & Reduced blood pressure \\
\hline
\end{tabular}


dietary changes. The decline in insulin resistance and the reduced risk in the risk variant TCF7L2 can be attributed to lifestyle modification [182-184].

There lies a shared SNP in obesity-linked genes such as FTO rs9939609 and fat mass. The SNP is linked with the increased vulnerability to T2DM. An increase in physical activity assists in reducing the FTO rs9939609induced obesity and the linked T2DM risk [185]. The allele GCKRrs780094 is an insulin raising allele, a result of SNP in glucokinase regulatory gene. The gene interaction with whole grain reduces the carrier fasting insulin levels [186]. The gene KCNQ1 belongs to the subfamily Q of potassium voltage-gated channel and is a susceptible gene to T2DM. Mutation in this gene results in a decline in insulin secretion. The reduced expression of the Kcnq1 gene noncoding RNA Kcnq1ot1 region leads to an increment in Cdkn1c (cyclin-dependent kinase inhibitor $1 \mathrm{C}$ ) expression that ultimately results in the decline of insulin release and cell mass of pancreaticbeta cells. The concentration of C/EBPbeta in the beta cells of the pancreas elevates in the existence of a highfat diet and thus potentiates the dysfunction of beta cells in the susceptible population [182].

Reduction in hyperglycemia is also witnessed when there is an increment in the T2DM related genes (SLC26A3, GABAAalpha1, SLC26A6, CIC1-7, CFTR, and Bestrophin-3) expression due to the presence of Lactobacillus casei-a gut microbe [187]. There is an urgent need to consider the possible interplay between multiple T2DM linked genes and lifestyle modifications as it can turn out to be an effective therapeutic intervention.

\section{Medical nutrition therapy in the management and prevention of diabetes There lies a direct correlation between diabetes management and diet and therefore medical nutrition therapy (MNT) serves as a comple- ment to the traditional pharmacological intervention. The American Diabetes Association (ADA) recom- mended personalized MNT to individuals who are dia- betic or pre-diabetic for effective treatment by the registered dietician having proper knowledge of diabetes MNT [188]. The combination of MNT and medical treatment has the potential for effective diabetes treatment.}

MNT can be defined as the nutritional diagnosis and treatment to manage a particular disease furnished by a nutritional professional or a registered dietician. It also provides proper counseling service to the patient. The nutrition counseling of MNT provides a supportive process with priorities in order and to establish goals. It also involves the creation of individualized action plans to foster and acknowledge self-care [189].
The effectiveness of MNT in the treatment of diabetes I and diabetes II has been demonstrated by research. In 18 studies reviewed by the American Dietetic Association in which the individuals were provided with the MNT by a registered dietician as a complement to the treatment demonstrated a positive effect of medical nutrition therapy on the management of diabetes by showing an improvement in the levels of A1C [190]. It has been postulated by the ADA that MNT has potential in effective diabetes management whether type I or II.

Several studies adapted from Pastors et al. in which MNT was included in the diabetes treatment intervention reported a 0.9 to $1.9 \%$ improvement in the $\mathrm{A} 1 \mathrm{C}$ levels [191]. MNT has also successfully shown its role in preventing type 2 diabetes. It has also been postulated that the type 2 diabetes onset can also be delayed with lifestyle modification such as changes in diet. The diabetes prevention program, 2002, is a notable prevention study. A total of 1079 participants aged 25-84 received an intensive lifestyle intervention that comprised MNT showed a $58 \%$ decline in the incidence of diabetes over 3 years. The study was controlled and randomized. MNT shows a positive role in the management and prevention of type II diabetes in adults as shown in Table 9 but the same role of MNT is yet to be demonstrated for children and adolescents.

Chrono pharmacology and diabetes treatment The study of the drug effects variation with the biological timing of the endogenous periods is known as chronopharmacology. The main aim behind chronopharmacology lies in understanding the predictable and periodic changes in both the desired and undesired effects of a drug. Chronopharmacology may be divided into chronopharmacokinetics, chronotherapy, and chronotoxicity [198]. Chronopharmacological aspects have shown to have an important role in the treatment and management of diabetes mellitus as the timing of medication and patient activities can have a major impact on the occurrence of troughs and peak in blood glucose levels [199].

Changes in the biological clock are associated with increased rates of myocardial infarction. The misalignment in circadian cycles and behavioral cycle results in adversarial cardiometabolic endpoints such as increased arterial blood pressure, insulin, glucose, catecholamines, and cortisol [200]. Circadian rhythm influences both the insulin release as well as the counterregulatory hormones such as glucagon, cortisol, growth hormone, and epinephrine that increase the blood glucose levels when needed. There is an increase in the level of growth hormone followed by a cortisol release surge and results in an overall elevated glucose production level by the liver in the middle of the night. In people not suffering from 
Table 9 Goals of MNT in diabetes management

\begin{tabular}{ll}
\hline Goals of MNT in diabetes management & Result \\
\hline A1C $<7 \%$ & Decline the risk of microvascular complications [192] \\
Blood pressure $<140 / 180 \mathrm{mmHg}$ & Reduce risk for cardiovascular complications [193, 194] \\
$\mathrm{LDL}$ cholesterol $<100 \mathrm{mg} / \mathrm{dL}$ & Reduce risk for cardiovascular complications [193, 194] \\
Maintain body weight & Glycemic management \\
Address individual nutrition needs & Maintain energy balance \\
Maintain eating pleasure by educating about choices of food & Maintain energy balance and body weight \\
Day to day meal planning & Maintain energy balance and body weight [195-197] \\
\hline
\end{tabular}

diabetes, this increase in glucose is counteracted by the increased release of insulin in the pancreas and thus the glucose level remains constant. But, for people who suffer from type I diabetes and type II diabetes, the rise in blood glucose levels during sleep can have a significant effect on morning blood glucose levels. Blood glucose level rises between $4 \mathrm{am}$ to $8 \mathrm{am}$ and the event is known as the "dawn phenomenon." Circadian misalignment has been found to increase the resistance of insulin and decrease the function of the pancreas [201].

Daily rhythmicity is exhibited by both the pancreatic insulin secretion and the target organs of insulin. This daily rhythmicity may be associated with glucose metabolism homeostasis maintenance for an effective treatment of diabetes. It is necessary to correct these rhythms in diabetic patients. Several medications like glinides and long- and rapid-acting insulin analogs that are used to correct the impaired secretion of insulin have shown the chronotherapeutic approach. They are not only helpful in glycemic control but also reduce the risk of prolonged hypoglycemia and weight gain of the body. Lifestyle modifications affect the biological clock of humans. A therapeutic agent is required for the correction of the impaired biological clock as it is challenging to alter lifestyles in modern societies [202, 203].

\section{Future prospects}

While several studies led to the deeper comprehension of DM in the field of CVD, more work is needed to enhance the recognition and quantification of the threat of $\mathrm{CV}$ in DM patients. Further investigation is required to decide how glycemic regulation correlates to CVD. Some research indicates that better glycemic regulation potentially improves $\mathrm{CV}$ results for DM patients [73, 204]. Researchers need further analysis to help to understand the connection among glycemic control and CVD growth, and to decide whether beginning and length of therapy are relevant in reducing events of $\mathrm{CV}$ in DM patients. Additional studies are also required to figure out the best way of reducing cardiomyopathy and CAN risk and severity in DM patients. Several findings have also shown that autonomous dysfunction and cardiomyopathy of diabetes are disorder pathways that are normal in DM patients and raise the risk of potential CV problems. Modifying lifestyle, greater regulation and active compounds seem to be of help in reducing CAN and cardiomyopathy of diabetes development [205-208]. Nevertheless, fewer researchers have analyzed the most appropriate possible treatment for these problems and what could be done to avoid the creation of such systems. More work is required to better understand the regulation and management in people with diabetes of the typical risk factors of CVs, like blood pressure, obesity, and dyslipidemia. In comparison with the currently prescribed guidance based solely on statin prophylaxis, drug combination could be the best method of treating dyslipidemia. Further studies such as IMPROVE-IT will help to decide what treatment is best for treating diabetic dyslipidemia [208]. Additionally, HDL's function in CV healthcare is unclear and further work is required to evaluate whether pharmacologic drugs intended to boost HDL are clinically beneficial to people with diabetes.

It also is uncertain if losing weight in patients with diabetes is appropriate for the clinically important enhancement of $\mathrm{CV}$ production as well as how much dieting is needed. In people with diabetes with the other CV risk factors and co-morbidities, 5\% losing weight may not even be appropriate. Eventually, follow-ups on the latest blood pressure recommendations will have to be monitored closely, especially in individuals above 60 years.

\section{Conclusion}

The related CVD could also be predicted to increase as the incidence of DM keeps growing, due to both the conventional factors of risk of DM and the direct impact on CVD. Appropriate treatment and management of DM together with successful therapy of related risk factors are therefore important for reducing DM and CVD's increasing prevalence and advancement. Further work to enhance knowledge of the disease state and its impact 


\section{on $\mathrm{CV}$ function is required to boost medical treatment and $\mathrm{CV}$ results in people with diabetes.}

\section{Acknowledgements}

None

\section{Authors' contributions}

AS contributed to drafting, design of data; SM contributed to data revision and review; RA contributed to drafting, design, and analysis of data. MKC contributed to draft revision and data interpretation. All "Authors" have read and approved the manuscript.

\section{Funding}

This research did not receive any specific grant from funding agencies in the public, commercial, or not-for-profit sectors.

\section{Availability of data and materials}

Data and materials are available upon request.

\section{Ethics approval and consent to participate}

Not applicable.

\section{Consent for publication}

Not applicable.

\section{Competing interests}

The authors declare that they have no competing interests.

Received: 24 September 2020 Accepted: 30 November 2020

Published online: 09 December 2020

\section{References}

1. Saeedi P, Petersohn I, Salpea P, Malanda B, Karuranga S, Unwin N, Colagiuri S, Guariguata L, Motala AA, Ogurtsova K, Shaw JE, Bright D, Williams R (2019) Global and regional diabetes prevalence estimates for 2019 and projections for 2030 and 2045: results from the International Diabetes Federation Diabetes Atlas, 9th edition. Diabetes Res Clin Pract 157. https:// doi.org/10.1016/j.diabres.2019.107843

2. Kharroubi AT (2015) Diabetes mellitus: the epidemic of the century. World J Diabetes 6:850. https://doi.org/10.4239/wjd.v6.16.850

3. Bahia LR, Araujo DV, Schaan BD, Dib SA, Negrato CA, Leo MPS, Ramos AJS, Forti AC, Gomes MB, Foss MC, Monteiro RA, Sartorelli D, Franco LJ (2011) The costs of type 2 diabetes mellitus outpatient care in the Brazilian Public Health System. Value Heal 14:S137-S140. https://doi.org/10.1016/j.jval.2011. 05.009

4. Yang W, Dall TM, Beronjia K, Lin J, Semilla AP, Chakrabarti R, Hogan PF, Petersen MP (2018) Economic costs of diabetes in the U.S. in 2017. Diabetes Care 41:917-928. https://doi.org/10.2337/dci18-0007

5. Low Wang CC, Hess CN, Hiatt WR, Goldfine AB (2016) Clinical update: cardiovascular disease in diabetes mellitus. Circulation 133:2459-2502

6. Centers for Disease Control and Prevention (2014) National Diabetes Statistics Report: estimates of diabetes and its burden in the United States. US Dep Heal Hum Serv 2014, Report no: CS 314227-A

7. Russo GT, Baggio G, Rossi MC, Kautzky-Willer A (2015) Type 2 diabetes and cardiovascular risk in women. Int J Endocrinol 39:558-568

8. Schmidt AM (2019) Diabetes mellitus and cardiovascular disease. Arterioscler Thromb Vasc Biol 39:558-568

9. Naser KA, Gruber A, Thomson GA (2006) The emerging pandemic of obesity and diabetes: are we doing enough to prevent a disaster? Int J Clin Pract. 60:1093-1097

10. Cercato C, Fonseca FA (2019) Cardiovascular risk and obesity. Diabetol Metab Syndr. 11:74

11. Arner P, Rydén M (2015) Fatty acids, obesity and insulin resistance. Obes Facts 8:147-155. https://doi.org/10.1159/000381224

12. Aguiar C, Duarte R, Carvalho D (2019) New approach to diabetes care: from blood glucose to cardiovascular disease. Rev Port Cardiol 38:53-63. https:// doi.org/10.1016/j.repce.2019.01.001

13. Szekely Y, Arbel $Y$ (2018) A review of interleukin-1 in heart disease: where do we stand today? Cardiol Ther 7:25-44. https://doi.org/10.1007/s40119018-0104-3
14. Leifheit-Nestler M, Wagner NM, Gogiraju R, Didié M, Konstantinides S, Hasenfuss G, Schäfer K (2013) Importance of leptin signaling and signal transducer and activator of transcription-3 activation in mediating the cardiac hypertrophy associated with obesity. J Transl Med 11:170. https:// doi.org/10.1186/1479-5876-11-170

15. Luo JW, Zheng X, Cheng GC, Ye QH, Deng YZ, Wu L (2016) Resistin-induced cardiomyocyte hypertrophy is inhibited by apelin through the inactivation of extracellular signal-regulated kinase signaling pathway in $\mathrm{H} 9 \mathrm{C2}$ embryonic rat cardiomyocytes. Biomed Rep 5:473-478. https://doi.org/10. 3892/br.2016.749

16. Adiloğlu S, I, Yu C, Chen R, Li JJ, Li JJ, Drahansky M, Paridah M., Moradbak A Mohamed A., Owolabi, FolaLi H abdulwahab taiwo, Asniza M, Abdul Khalid SH., Sharma T, Dohare N, Kumari M, Singh UK, Khan AB, Borse MS, Patel R, Paez A, Howe A, Goldschmidt D, Corporation C, Coates J, Reading F (2012) We are IntechOpen, the world's leading publisher of open access books built by scientists, for scientists TOP 1\%. Intech i:13. doi: https://doi.org/10. 1016/j.colsurfa.2011.12.014

17. Mamo Y, Bekele F, Nigussie T, Zewudie A (2019) Determinants of poor glycemic control among adult patients with type 2 diabetes mellitus in Jimma University Medical Center, Jimma zone, south west Ethiopia: a case control study. BMC Endocr Disord 19:1-11. https://doi.org/10.1186/s12902019-0421-0

18. Mezza T, Cinti F, Cefalo CMA, Pontecorvi A, Kulkarni RN, Giaccari A (2019) Bcell fate in human insulin resistance and type 2 diabetes: a perspective on islet plasticity. Diabetes 68:1121-1129

19. Ragheb RM, Medhat A (2011) Mechanisms of fatty acid-induced insulin resistance in muscle and liver. J Diabetes Metab 02: doi: https://doi.org/10. 4172/2155-6156.1000127

20. Konigorski S, Janke J, Drogan D, Bergmann MM, Hierholzer J, Kaaks R, Boeing H, Pischon T (2019) Prediction of circulating adipokine levels based on body fat compartments and adipose tissue gene expression. Obes Facts 12:590-605. https://doi.org/10.1159/000502117

21. Shimobayashi M, Albert V, Woelnerhanssen B, Frei IC, Weissenberger D, Meyer-Gerspach AC, Clement N, Moes S, Colombi M, Meier JA, Swierczynska MM, Jenö P, Beglinger C, Peterli R, Hall MN (2018) Insulin resistance causes inflammation in adipose tissue. J Clin Invest 128:1538-1550. https://doi.org/ 10.1172/JC196139

22. Rasooly RS, Akolkar B, Spain LM, Guill MH, Del Vecchio CT, Carroll LE (2015) The national institute of diabetes and digestive and kidney diseases central repositories: a valuable resource for nephrology research. Clin J Am Soc Nephrol 10:710-715. https://doi.org/10.2215/CJN.06570714

23. Shaikh A (2017) A practical approach to hypertension management in diabetes. Diabetes Ther. 8:981-989

24. Kostis JB, Wilson AC, Freudenberger RS, Cosgrove NM, Pressel SL, Davis BR (2005) Long-term effect of diuretic-based therapy on fatal outcomes in subjects with isolated systolic hypertension with and without diabetes. Am J Cardiol 95:29-35. https://doi.org/10.1016/j.amjcard.2004.08.059

25. KV, Mohammed M (2014) Prevalence of hypertension in type-2 diabetes mellitus. CHRISMED J Heal Res 1:223 . doi: https//doi.org/10.4103/2348-3334.142981

26. Group TDC and CTR (1993) The effect of intensive treatment of diabetes on the development and progression of long-term complications in insulindependent diabetes mellitus. N Engl J Med 329:977-986. https://doi.org/10. 1056/NEJM199309303291401

27. Vogt L, Roelofs JJ (2019) Introduction to pathogenetic mechanisms of diabetic nephropathy. In: Diabetic Nephropathy. Springer International Publishing, Cham pp 83-87

28. Okada H, Watanabe Y, Kikuta T, Kobayashi T, Kanno Y, Sugaya T, Suzuki H (2004) Bradykinin decreases plasminogen activator inhibitor-1 expression and facilitates matrix degradation in the renal tubulointerstitium under angiotensin-converting enzyme blockade. J Am Soc Nephrol 15:2404-2413. https://doi.org/10.1097/01.ASN.0000136132.20189.95

29. Cheung BMY (2011) Drug treatment for obesity in the post-sibutramine era. Drug Saf. 34:641-650

30. Cheung BMY, Li C (2012) Diabetes and hypertension: is there a common metabolic pathway? Curr Atheroscler Rep. 14:160-166

31. Qazi MU, Malik S (2013) Diabetes and cardiovascular disease: insights from the Framingham Heart Study. Glob Heart 8:43-48

32. Schofield JD, Liu Y, Rao-Balakrishna P, Malik RA, Soran H (2016) Diabetes dyslipidemia. Diabetes Ther. 7:203-219

33. Abd-Allha E, Hassan B, Abduo M, Omar S, Sliem H (2014) Small dense lowdensity lipoprotein as a potential risk factor of nephropathy in type 2 
diabetes mellitus. Indian J Endocrinol Metab 18:94-98. https://doi.org/10 4103/2230-8210.126585

34. De Ferranti SD, De Boer IH, Fonseca V, Fox CS, Golden SH, Lavie CJ, Magge SN, Marx N, McGuire DK, Orchard TJ, Zinman B, Eckel RH (2014) Type 1 diabetes mellitus and cardiovascular disease: a scientific statement from the American Heart Association and American Diabetes Association. Diabetes Care 37:2843-2863

35. Krauss RM (2004) Lipids and lipoproteins in patients with type 2 diabetes. Diabetes Care 27:1496-1504. https://doi.org/10.2337/diacare.27.6.1496

36. Wu L, Parhofer KG (2014) Diabetic dyslipidemia. Metabolism. 63:1469-1479

37. Ginsberg HN, Maccallum PR (2009) The obesity, metabolic syndrome, and type 2 diabetes mellitus pandemic: part I. Increased cardiovascular disease risk and the importance of atherogenic dyslipidemia in persons with the metabolic syndrome and type 2 diabetes mellitus. J. Cardiometab. Syndr. 4: 113-119

38. Sheth J, Shah A, Sheth F, Trivedi S, Nabar N, Shah N, Thakor P, Vaidya R (2015) The association of dyslipidemia and obesity with glycated hemoglobin. Clin Diabetes Endocrinol 1:6. https://doi.org/10.1186/s40842015-0004-6

39. Bays HE, Maki KC, McKenney J, Snipes R, Meadowcroft A, Schroyer R, Doyle RT, Stein E (2010) Long-term up to 24-month efficacy and safety of concomitant prescription omega-3-acid ethyl esters and simvastatin in hypertriglyceridemic patients. Curr Med Res Opin 26:907-915. https://doi. org/10.1185/03007991003645318

40. Jain R, Olejas S, Davey S, Jain R, Shoghli R (2019) Diabetes \& dyslipidaemia goals in management of diabetes. J Diab Metab Disord Control 6:99-102. https://doi.org/10.15406/jdmdc.2019.06.00189

41. Jia G, Hill MA, Sowers JR (2018) Diabetic cardiomyopathy: an update of mechanisms contributing to this clinical entity. Circ. Res. 122:624-638

42. Negishi K (2018) Echocardiographic feature of diabetic cardiomyopathy: where are we now? Cardiovasc Diagn Ther. 8:47-56

43. Santra S, Basu AK, Roychowdhury P, Banerjee R, Singhania P, Singh S, Datta UK (2011) Comparison of left ventricular mass in normotensive type 2 diabetes mellitus patients with that in the nondiabetic population. J Cardiovasc Dis Res 2:50-56. https://doi.org/10.4103/0975-3583.78597

44. Hall ME, Harmancey R, Stec DE (2015) Lean heart: role of leptin in cardiac hypertrophy and metabolism. World J Cardiol 7:511. https://doi.org/10.4330/ wjc.V7.19.511

45. Lebeche D (2015) Diabetic cardiomyopathy: is resistin a culprit? Cardiovasc Diagn Ther 5:387-38793. https://doi.org/10.3978/j.issn.2223-3652.2015.05.04

46. Patel S, Chauhan H, Amin G (2017) Diastolic dysfunction in asymptomatic type 2 diabetes mellitus (OK)tk.pdf. Echocardiogr. NJIRM 8:66-70

47. Bergerot C, Davidsen ES, Amaz C, Thibault H, Altman M, Bellaton A, Moulin P, Derumeaux G, Ernande L (2018) Diastolic function deterioration in type 2 diabetes mellitus: predictive factors over a 3-year follow-up. Eur Heart J Cardiovasc Imaging 19:67-73. https://doi.org/10.1093/ehjci/jew331

48. Tacito LHB, Pires AC, Yugar-Toledo JC (2017) Impaired flow-mediated dilation response and carotid intima-media thickness in patients with type 1 diabetes mellitus with a mean disease duration of 4.1 years. Arch Endocrinol Metab 61:542-549. https://doi.org/10.1590/2359-3997000000281

49. Sharma S, Adrogue JV, Golfman L, Uray I, Lemm J, Youker K, Noon GP, Frazier $\mathrm{OH}$, Taegtmeyer $\mathrm{H}$ (2004) Intramyocardial lipid accumulation in the failing human heart resembles the lipotoxic rat heart. FASEB J 18:1692-1700. https://doi.org/10.1096/fj.04-2263com

50. Aasum E, Hafstad AD, Severson DL, Larsen TS (2003) Age-dependent changes in metabolism, contractile function, and ischemic sensitivity in hearts from db/db mice. Diabetes 52:434-441. https://doi.org/10.2337/ diabetes.52.2.434

51. Gao Y, Ren Y, Guo YK, Liu X, Xie LJ, Jiang L, Shen MT, Deng MY, Yang ZG (2020) Metabolic syndrome and myocardium steatosis in subclinical type 2 diabetes mellitus: a $1 \mathrm{H}$-magnetic resonance spectroscopy study. Cardiovasc Diabetol 19:70. https://doi.org/10.1186/s12933-020-01044-1

52. McGavock JM, Lingvay I, Zib I, Tillery T, Salas N, Unger R, Levine BD, Raskin P, Victor RG, Szczepaniak LS (2007) Cardiac steatosis in diabetes mellitus: a 1H-magnetic resonance spectroscopy study. Circulation 116:1170-1175. https://doi.org/10.1161/CIRCULATIONAHA.106.645614

53. Bax JJ, Young LH, Frye RL, Bonow RO, Steinberg HO, Barrett EJ (2007) Screening for coronary artery disease in patients with diabetes. In: Diabetes Care. American Diabetes Association, pp 2729-2736

54. Yu CM, Chau E, Sanderson JE, Fan K, Tang MO, Fung WH, Lin H, Kong SL, Lam YM, Hill MRS, Lau CP (2002) Tissue Doppler echocardiographic evidence of reverse remodeling and improved synchronicity by simultaneously delaying regional contraction after biventricular pacing therapy in heart failure. Circulation 105:438-445. https://doi.org/10.1161/ hc0402.102623

55. Ng AC, Delgado V, Bertini M, Ewe SH, van der Meer RW, Rijzewijk LJ, Siebelink H-M, Smit JW, Diamant M, Romijn JA, de Roos A, Leung DY, Lamb HJ, Bax JJ (2010) Myocardial steatosis and left ventricular strain and strain rate imaging in patients with type 2 mellitus. J Am Coll Cardiol 55:A93.E880. https://doi.org/10.1016/s0735-1097(10)60881-9

56. Ng ACT, Delgado V, Bertini M, Van Der Meer RW, Rijzewijk LJ, Hooi Ewe S, Siebelink HM, Smit JWA, Diamant M, Romijn JA, De Roos A, Leung DY, Lamb HJ, Bax JJ (2010) Myocardial steatosis and biventricular strain and strain rate imaging in patients with type 2 diabetes mellitus. Circulation 122 2538-2544. https://doi.org/10.1161/CIRCULATIONAHA.110.955542diabetes

57. Ringle A, Dornhorst A, Rehman MB, Ruisanchez C, Nihoyannopoulos P (2017) Evolution of subclinical myocardial dysfunction detected by twodimensional and three-dimensional speckle tracking in asymptomatic type 1 diabetic patients: a long-term follow-up study. Echo Res Pract 4:73-81. https://doi.org/10.1530/ERP-17-0052

58. Paolillo S, Rengo G, Pagano G, Pellegrino T, Savarese G, Femminella GD, Tuccillo M, Boemio A, Attena E, Formisano R, Petraglia L, Scopacasa F, Galasso G, Leosco D, Trimarco B, Cuocolo A, Perrone-Filardi P (2013) Impact of diabetes on cardiac sympathetic innervation in patients with heart failure: a 1231 meta-iodobenzylguanidine (123I MIBG) scintigraphic study. Diabetes Care 36:2395-2401. https://doi.org/10.2337/dc12-2147

59. Regan TJ, Lyons MM, Ahmed SS (1977) Evidence for cardiomyopathy in familial diabetes mellitus. J Clin Invest 60:885-899. https://doi.org/10.1172/ JCl108843

60. Tribouilloy C, Rusinaru D, Mahjoub H, Tartière JM, Kesri-Tartière L, Godard S, Peltier M (2008) Prognostic impact of diabetes mellitus in patients with heart failure and preserved ejection fraction: a prospective five-year study. Heart 94:1450-1455. https://doi.org/10.1136/hrt.2007.128769

61. Meagher P, Adam M, Civitarese R, Bugyei-Twum A, Connelly KA (2018) Heart Failure with preserved ejection fraction in diabetes: mechanisms and management. Can J Cardiol. 34:632-643

62. Wilkinson MJ, Zadourian A, Taub PR (2019) Heart failure and diabetes mellitus: defining the problem and exploring the interrelationship. Am J Cardiol. 124:S3-S11

63. Spallone V (2019) Update on the impact, diagnosis and management of cardiovascular autonomic neuropathy in diabetes: what is defined, what is new, and what is unmet. Diabetes Metab. J. 43:3-30

64. Moningi S, Nikhar S, Ramachandran G (2018) Autonomic disturbances in diabetes: assessment and anaesthetic implications. Indian J Anaesth. 62: 575-583

65. Agashe S, Petak S (2018) Cardiac autonomic neuropathy in diabetes mellitus. Methodist Debakey Cardiovasc. J. 14:251-256

66. Fisher VL, Tahrani AA (2017) Cardiac autonomic neuropathy in patients with diabetes mellitus: current perspectives. Diabetes, Metab. Syndr. Obes. Targets Ther. 10:419-434

67. Ait-Oufella H, Taleb S, Mallat Z, Tedgui A (2011) Recent advances on the role of cytokines in atherosclerosis. Arterioscler Thromb Vasc Biol 31:969979. https://doi.org/10.1161/ATVBAHA.110.207415

68. Vinik Al, Maser RE, Ziegler D (2011) Autonomic imbalance: prophet of doom or scope for hope? Diabet Med 28:643-651. https://doi.org/10.1111/j.14645491.2010.03184.x

69. Lampert R, Bremner JD, Su S, Miller A, Lee F, Cheema F, Goldberg J, Vaccarino V (2008) Decreased heart rate variability is associated with higher levels of inflammation in middle-aged men. Am Heart J 156:759.e1-759.e7. https://doi.org/10.1016/j.ahj.2008.07.009

70. Prince $C T$, Secrest AM, Mackey RH, Arena VC, Kingsley LA, Orchard TJ (2010) Cardiovascular autonomic neuropathy, HDL cholesterol, and smoking correlate with arterial stiffness markers determined 18 years later in type 1 diabetes. Diabetes Care 33:652-657. https://doi.org/10. 2337/dc09-1936

71. Spallone V, Ziegler D, Freeman R, Bernardi L, Frontoni S, Pop-Busui R, Stevens M, Kempler P, Hilsted J, Tesfaye S, Low P, Valensi P (2011) Cardiovascular autonomic neuropathy in diabetes: clinical impact, assessment, diagnosis, and management. Diabetes Metab Res Rev. 27:639653

72. Schmid H (2007) Cardiovascular impact of the autonomic neuropathy of diabetes mellitus. Arq Bras Endocrinol Metabol. 51:232-243 
73. Pop-Busui R (2010) Cardiac autonomic neuropathy in diabetes: a clinical perspective. Diabetes Care 33:434-441

74. Vinik Al, Erbas T, Casellini CM (2013) Diabetic cardiac autonomic neuropathy, inflammation and cardiovascular disease. J. Diabetes Investig. 4: 4-18

75. Brownlee M (2001) Biochemistry and molecular cell biology of diabetic complications. Nature 414:813-820

76. Rhee SY, Kim YS (2018) The role of advanced glycation end products in diabetic vascular complications. Diabetes Metab J 42:188-195. https://doi. org/10.4093/dmj.2017.0105

77. Cerami C, Founds H, Nicholl I, Mitsuhashi T, Giordano D, Vanpatten S, Lee A, Al-Abed Y, Vlassara H, Bucala R, Cerami A (1997) Tobacco smoke is a source of toxic reactive glycation products. Proc Natl Acad Sci U S A 94:1391513920. https://doi.org/10.1073/pnas.94.25.13915

78. Koschinsky T, He CJ, Mitsuhashi T, Bucala R, Liu C, Buenting C, Heitmann K, Vlassara H (1997) Orally absorbed reactive glycation products (glycotoxins): an environmental risk factor in diabetic nephropathy. Proc Natl Acad Sci U S A 94:6474-6479. https://doi.org/10.1073/pnas.94.12.6474

79. Nicholl ID, Stitt AW, Moore JE, Ritchie AJ, Archer DB, Bucala R (1998) Increased levels of advanced glycation endproducts in the lenses and blood vessels of cigarette smokers. Mol Med 4:594-601. https://doi.org/10.1007/ bf03401759

80. Vlassara H, Cai W, Crandall J, Goldberg T, Oberstein R, Dardaine V, Peppa M, Rayfield EJ (2002) Inflammatory mediators are induced by dietary glycotoxins, a major risk factor for diabetic angiopathy. Proc Natl Acad Sci U S A 99:15596-15601. https://doi.org/10.1073/pnas.242407999

81. Schalkwijk CG, Miyata T (2012) Early- and advanced non-enzymatic glycation in diabetic vascular complications: the search for therapeutics. Amino Acids 42:1193-1204

82. Chaudhuri J, Bains Y, Guha S, Kahn A, Hall D, Bose N, Gugliucci A, Kapahi P (2018) The role of advanced glycation end products in aging and metabolic diseases: bridging association and causality. Cell Metab. 28:337-352

83. Makita Z, Bucala R, Rayfield EJ, Fuh H, Manogue KR, Cerami A, Viassara H, Friedman EA, Kaufman AM, Korbet SM, Barth RH, Winston JA (1994) Reactive glycosylation endproducts in diabetic uraemia and treatment of renal failure. Lancet 343:1519-1522. https://doi.org/10.1016/S0140-6736(94)929351

84. Soulis-Liparota T, Cooper ME, Dunlop M, Jerums G (1995) The relative roles of advanced glycation, oxidation and aldose reductase inhibition in the development of experimental diabetic nephropathy in the Sprague-Dawley rat. Diabetologia 38:387-394. https://doi.org/10.1007/BF00410275

85. Oldfield MD, Bach LA, Forbes JM, Nikolic-Paterson D, McRobert A, Thallas V, Atkins RC, Osicka T, Jerums G, Cooper ME (2001) Advanced glycation end products cause epithelial-myofibroblast transdifferentiation via the receptor for advanced glycation end products (RAGE). J Clin Invest 108:1853-1863. https://doi.org/10.1172/JC111951

86. Xu J, Chen LJ, Yu J, Wang HJ, Zhang F, Liu Q, Wu J (2018) Involvement of advanced glycation end products in the pathogenesis of diabetic retinopathy. Cell Physiol Biochem 48:705-717

87. Stitt AW (2001) Advanced glycation: an important pathological event in diabetic and age related ocular disease. Br J Ophthalmol 85:746-753

88. Stitt AW, Li YM, Gardiner TA, Bucala R, Archer DB, Vlassara H (1997) Advanced glycation end products (AGEs) co-localize with AGE receptors in the retinal vasculature of diabetic and of AGE-infused rats. Am J Pathol 150: $523-531$

89. Stitt AW, Bhaduri T, McMullen CBT, Gardiner TA, Archer DB (2000) Advanced glycation end products induce blood-retinal barrier dysfunction in normoglycemic rats. Mol Cell Biol Res Commun 3:380-388. https://doi.org/ $10.1006 / \mathrm{mcbr} .2000 .0243$

90. Chen AS, Taguchi T, Sugiura M, Wakasugi Y, Kamei A, Wang MW, Miwa I (2004) Pyridoxal-aminoguanidine adduct is more effective than aminoguanidine in preventing neuropathy and cataract in diabetic rats. Horm Metab Res 36:183-187. https://doi.org/10.1055/s-2004-814344

91. Fishman SL, Sonmez H, Basman C, Singh V, Poretsky L (2018) The role of advanced glycation end-products in the development of coronary artery disease in patients with and without diabetes mellitus: a review. Mol Med 24(1):59

92. Sobenin IA, Tertov W, Koschinsky $T$, Bünting $C E$, Slavina ES, Dedovc II, Orekhov AN (1993) Modified low density lipoprotein from diabetic patients causes cholesterol accumulation in human intimal aortic cells. Atherosclerosis 100:41-54. https://doi.org/10.1016/0021-9150(93)90066-4
93. Linssen PBC, Henry RMA, Schalkwijk CG, Dekker JM, Nijpels G, Brunner-La Rocca HP, Stehouwer CDA (2016) Serum advanced glycation endproducts are associated with left ventricular dysfunction in normal glucose metabolism but not in type 2 diabetes: the Hoorn Study. Diabetes Vasc Dis Res 13:278-285. https://doi.org/10.1177/1479164116640680

94. Lapolla A, Piarulli F, Sartore G, Ceriello A, Ragazzi E, Reitano R, Baccarin L, Laverda B, Fedele D (2007) Advanced glycation end products and antioxidant status in type 2 diabetic patients with and without peripheral artery disease. Diabetes Care 30:670-676. https://doi.org/10. 2337/dc06-1508

95. Cooper ME, Bonnet F, Oldfield M, Jandeleit-Dahm K (2001) Mechanisms of diabetic vasculopathy: an overview. Am J Hypertens. 14:475-486

96. Saxena S, Mishra A, Saxena A, Natu SM (2012) Advanced glycation end products and diabetic retinopathy Yashodhara Sharma1. J Ocul Biol Dis Infor 5:63-69. https://doi.org/10.1007/s12177-013-9104-7

97. Ma RC (2016) Genetics of cardiovascular and renal complications in diabetes. J Diabetes Investig 7:139-154. https://doi.org/10.1111/jdi.12391

98. Pradeepa R, Nazir A, Mohan V (2014) Type 2 diabetes and cardiovascular diseases: do they share a common soil? The Asian Indian experience. Heart Asia 4:69-76. https://doi.org/10.1136/heartasia-2011-010081

99. De Rosa S, Curcio A, Indolfi C (2014) Emerging role of micrornas in cardiovascular diseases. Circ J. 78:567-575

100. Gareri C, De Rosa S, Indolfi C (2016) MicroRNAs for restenosis and thrombosis after vascular injury. Circ Res. 118:1170-1184

101. Association AD (2018) Classification and diagnosis of diabetes: standards of medical care in Diabetes 2018. Diabetes Care 41:S13-S27. https://doi.org/10. 2337/dc18-S002

102. O'Donnell CJ, Nabel EG (2011) Genomics of cardiovascular disease. N Engl J Med 365:2098-2109. https://doi.org/10.1056/nejmra1105239

103. Besseling J, Kastelein JJP, Defesche JC, Hutten BA, Hovingh GK (2015) Association between familial hypercholesterolemia and prevalence of type 2 diabetes mellitus. JAMA 313:1029-1036. https://doi.org/10.1001/jama.2015.1206

104. Wang X, Strizich G, Hu Y, Wang T, Kaplan RC, Qi Q (2016) Genetic markers of type 2 diabetes: progress in genome-wide association studies and clinical application for risk prediction. J Diabetes 8:24-35

105. Kumar D (2018) Introduction to Genes, Genome and Inheritance. In: Kumar D., Elliott P. (eds) Cardiovascular Genetics and Genomics. Springer, Cham. https://doi.org/10.1007/978-3-319-66114-8_1

106. Muendlein A, Saely CH, Geller-Rhomberg S, Sonderegger G, Rein P, Winder T, Beer S, Vonbank A, Drexel H (2011) Single nucleotide polymorphisms of TCF7L2 are linked to diabetic coronary atherosclerosis. Plos One 6:e17978. https://doi.org/10.1371/journal.pone.0017978

107. Sousa AGP, Marquezine GF, Lemos PA, Martinez E, Lopes N, Hueb WA, Krieger JE, Pereira AC (2009) TCF7L2 polymorphism rs7903146 is associated with coronary artery disease severity and mortality. Plos One 4:e7697. https://doi.org/10.1371/journal.pone.0007697

108. Qi L, Parast L, Cai T, Powers C, Gervino EV, Hauser TH, Hu FB, Doria A (2011) Genetic susceptibility to coronary heart disease in type 2 diabetes: 3 independent studies. J Am Coll Cardiol 58:2675-2682. https://doi.org/10. 1016/j.jacc.2011.08.054

109. De Rosa S, Chiefari E, Salerno N, Ventura V, D'Ascoli GL, Arcidiacono B, Ambrosio G, Bilotta FL, Torella D, Foti D, Indolfi C, Brunetti A (2017) HMGA1 is a novel candidate gene for myocardial infarction susceptibility. Int J Cardiol 227:331-334. https://doi.org/10.1016/j.j.jcard.2016.11.088

110. Chiefari E, Tanyolaç S, Paonessa F, Pullinger CR, Capula C, liritano S, Mazza T, Forlin M, Fusco A, Durlach V, Durlach A, Malloy MJ, Kane JP, Heiner SW, Filocamo M, Foti DP, Goldfine ID, Brunetti A (2011) Functional variants of the HMGA1 gene and type 2 diabetes mellitus. JAMA 305:903-912. https:// doi.org/10.1001/jama.2011.207

111. Ruiz J, Morabia A, Blanche H, James RW, Garin MCB, Charpentier G, Passa P, Vaisse C, Ruiz J, Froguel P (1995) Gln-Arg192 polymorphism of paraoxonase and coronary heart disease in type 2 diabetes. Lancet 346:869-872. https:// doi.org/10.1016/S0140-6736(95)92709-3

112. Serrato M, Marian AJ (1995) A variant of human paraoxonase/arylesterase (HUMPONA) gene is a risk factor for coronary artery disease. J Clin Invest 96: 3005-3008. https://doi.org/10.1172/JC11 18373

113. Bacci S, Menzaghi C, Ercolino T, Ma X, Rauseo A, Salvemini L, Vigna C, Fanelli R, Di Mario U, Doria A, Trischitta V (2004) The +276 G/T single nucleotide polymorphism of the adiponectin gene is associated with coronary artery disease in type 2 diabetic patients. Diabetes Care 27:20152020. https://doi.org/10.2337/diacare.27.8.2015 
114. Lakka HM, Laaksonen DE, Lakka TA, Niskanen LK, Kumpusalo E, Tuomilehto J, Salonen JT (2002) The metabolic syndrome and total and cardiovascular disease mortality in middle-aged men. J Am Med Assoc 288:2709-2716. https://doi.org/10.1001/jama.288.21.2709

115. Malik S, Wong ND, Franklin SS, Kamath TV, L'Italien GJ, Pio JR, Williams GR (2004) Impact of the metabolic syndrome on mortality from coronary heart disease, cardiovascular disease, and all causes in United States adults. Circulation 110:1245-1250. https://doi.org/10.1161/01.CIR. 0000140677.20606.0E

116. Piché ME, Tchernof A, Després JP (2020) Obesity phenotypes, diabetes, and cardiovascular diseases. Circ Res:1477-1500. https://doi.org/10.1161/ CIRCRESAHA.120.316101

117. Haffner SM, Lehto S, Rönnemaa T, Pyörälä K, Laakso M (1998) Mortality from coronary heart disease in subjects with type 2 diabetes and in nondiabetic subjects with and without prior myocardial infarction. N Engl J Med 339: 229-234. https://doi.org/10.1056/NEJM199807233390404

118. James WPT, Caterson ID, Coutinho W, Finer N, Van Gaal LF, Maggioni AP, Torp-Pedersen C, Sharma AM, Shepherd GM, Rode RA, Renz CL (2010) Effect of sibutramine on cardiovascular outcomes in overweight and obese subjects. N Engl J Med 363:905-917. https://doi.org/10.1056/ NEJMoa1003114

119. Wing RR, Bolin P, Brancati FL, Bray GA, Clark JM, Coday M, Crow RS, Curtis JM, Egan CM, Espeland MA, Evans M, Foreyt JP, Ghazarian S, Gregg EW, Harrison B, Hazuda HP, Hill JO, Horton ES, Van Hubbard S, Jakicic JM, Jeffery RW, Johnson KC, Kahn SE, Kitabchi AE, Knowler WC, Lewis CE, MaschakCarey BJ, Montez MG, Murillo A, Nathan DM, Patricio J, Peters A, Pi-Sunyer X, Pownall H, Reboussin D, Regensteiner JG, Rickman AD, Ryan DH, Safford M, Wadden TA, Wagenknecht LE, West DS, Williamson DF, Yanovski SZ (2013) Cardiovascular effects of intensive lifestyle intervention in type 2 diabetes. $\mathrm{N}$ Engl J Med 369:145-154. https://doi.org/10.1056/NEJMoa1212914

120. Tuomilehto J, Lindström J, Eriksson JG, Valle TT, Hämäläinen $H$, llanneParikka P, Keinänen-Kiukaanniemi S, Laakso M, Louheranta A, Rastas M, Salminen V, Aunola S, Cepaitis Z, Moltchanov V, Hakumäki M, Mannelin M, Martikkala V, Sundvall J, Uusitupa M (2001) Prevention of type 2 diabetes mellitus by changes in lifestyle among subjects with impaired glucose tolerance. N Engl J Med 344:1343-1350. https://doi.org/10.1056/ nejm200105033441801

121. Aroda VR, Ratner RE (2018) Metformin and type 2 diabetes prevention. Diabetes Spectr 31:336-342. https://doi.org/10.2337/ds18-0020

122. Jensen MD, Ryan DH, Apovian CM, Ard JD, Comuzzie AG, Donato KA, Hu FB, Hubbard VS, Jakicic JM, Kushner RF, Loria CM, Millen BE, Nonas CA, PiSunyer FX, Stevens J, Stevens VJ, Wadden TA, Wolfe BM, Yanovski SZ (2014) 2013 AHA/ACC/TOS guideline for the management of overweight and obesity in adults: a report of the American College of cardiology/American Heart Association task force on practice guidelines and the obesity society. Circulation 129:S102-S138. https://doi.org/10.1161/01.cir.0000437739.71477. ee

123. Blüher M, Laufs U (2019) New concepts for body shape-related cardiovascular risk: role of fat distribution and adipose tissue function. Eur. Heart J. 40:2856-2858

124. Neeland IJ, Ross R, Després JP, Matsuzawa Y, Yamashita S, Shai I, Seidell J, Magni P, Santos RD, Arsenault B, Cuevas A, Hu FB, Griffin B, Zambon A, Barter P, Fruchart JC, Eckel RH (2019) Visceral and ectopic fat, atherosclerosis, and cardiometabolic disease: a position statement. Lancet Diabetes Endocrinol. 7:715-725

125. Ghosh RK, Ghosh GC, Gupta M, Bandyopadhyay D, Akhtar T, Deedwania P, Lavie CJ, Fonarow GC, Aneja A (2019) Sodium glucose co-transporter 2 inhibitors and heart failure. Am J Cardiol 124:1790-1796

126. Marso SP, Bain SC, Consoli A, Eliaschewitz FG, Jodar E, Leiter LA, Lingvay I, Rosenstock J, Seufert J, Warren ML, Woo V, Hansen O, Holst AG, Pettersson J, Vilsboll T (2016) Semaglutide and cardiovascular outcomes in patients with type 2 diabetes. N Engl J Med 375:1834-1844. https://doi.org/10.1056/ NEJMoa1607141

127. Zelniker TA, Wiviott SD, Raz I, Im K, Goodrich EL, Bonaca MP, Mosenzon O, Kato ET, Cahn A, Furtado RHM, Bhatt DL, Leiter LA, McGuire DK, Wilding JPH, Sabatine MS (2019) SGLT2 inhibitors for primary and secondary prevention of cardiovascular and renal outcomes in type 2 diabetes: a systematic review and meta-analysis of cardiovascular outcome trials. Lancet 393:31-39. https://doi.org/10.1016/S0140-6736(18)32590-X

128. Bethel MA, Patel RA, Merrill P, Lokhnygina Y, Buse JB, Mentz RJ, Pagidipati NJ, Chan JC, Gustavson SM, Iqbal N, Maggioni AP, Öhman P, Poulter NR,
Ramachandran A, Zinman B, Hernandez AF, Holman RR (2018) Cardiovascular outcomes with glucagon-like peptide-1 receptor agonists in patients with type 2 diabetes: a meta-analysis. Lancet Diabetes Endocrinol 6: 105-113. https://doi.org/10.1016/S2213-8587(17)30412-6

129. Padwal R, Klarenbach S, Wiebe N, Birch D, Karmali S, Manns B, Hazel M, Sharma AM, Tonelli M (2011) Bariatric surgery: a systematic review and network meta-analysis of randomized trials. Obes. Rev. 12:602-621

130. Schauer PR, Bhatt DL, Kirwan JP, Wolski K, Aminian A, Brethauer SA, Navaneethan SD, Singh RP, Pothier CE, Nissen SE, Kashyap SR (2017) Bariatric surgery versus intensive medical therapy for diabetes - 5-year outcomes. N Engl J Med 376:641-651. https://doi.org/10.1056/ NEJMoa1600869

131. Angrisani L, Santonicola A, lovino P, Vitiello A, Zundel N, Buchwald H, Scopinaro N (2017) Bariatric surgery and endoluminal procedures: IFSO Worldwide Survey 2014. Obes Surg 27:1-11. https://doi.org/10.1007/s11695017-2666-X

132. Piché MĖ, Auclair A, Harvey J, Marceau S, Poirier P (2015) How to choose and use bariatric surgery in 2015. Can J Cardiol. 31:153-166

133. Dadson $\mathrm{P}$, Landini L, Helmiö M, Hannukainen JC, Immonen $\mathrm{H}$, Honka MJ, Bucci M, Savisto N, Soinio M, Salminen P, Parkkola R, Pihlajamäki J, lozzo P, Ferrannini E, Nuutila P (2016) Effect of bariatric surgery on adipose tissue glucose metabolism in different depots in patients with or without type 2 diabetes. Diabetes Care 39:292-299. https://doi.org/10.2337/dc15-1447

134. Sjöström $L$ (2013) Review of the key results from the Swedish Obese Subjects (SOS) trial - a prospective controlled intervention study of bariatric surgery. J Intern Med. 273:219-234

135. Fisher DP, Johnson E, Haneuse S, Arterburn D, Coleman KJ, O'Connor PJ, O'Brien R, Bogart A, Theis MK, Anau J, Schroeder EB, Sidney S (2018) Association between bariatric surgery and macrovascular disease outcomes in patients with type 2 diabetes and severe obesity. JAMA 320:1570-1582. https://doi.org/10.1001/jama.2018.14619

136. McCloskey CA, Ramani GV, Mathier MA, Schauer PR, Eid GM, Mattar SG, Courcoulas AP, Ramanathan R (2007) Bariatric surgery improves cardiac function in morbidly obese patients with severe cardiomyopathy. Surg Obes Relat Dis 3:503-507. https://doi.org/10.1016/j.soard.2007.05.006

137. Ramani GV, McCloskey C, Ramanathan RC, Mathier MA (2008) Safety and efficacy of bariatric surgery in morbidly obese patients with severe systolic heart failure. Clin Cardiol 31:516-520. https://doi.org/10.1002/clc.20315

138. Whelton PK, Appel L, Charleston J, Dalcin AT, Ewart C, Fried L, Kaidy D, Klag MJ, Kumanyika S, Steffen L, Walker WG, Oberman A, Counts K, Hataway H, Raczynski J, Rappaport N, Weinsier R, Borhani NO, Bernauer E, Borhani P, de la Cruz C, Ertl A, Heustis D, Lee M, Lovelace W, O'Connor E, Peel L (1992) The effects of nonpharmacologic interventions on blood pressure of persons with high normal levels: results of the trials of hypertension prevention, phase I. JAMA 267:1213-1220. https://doi.org/10.1001/jama. 1992.03480090061028

139. Barzilay Jl, Davis BR, Bettencourt J, Margolis KL, Goff DC, Black H, Habib G, Ellsworth A, Force RW, Wiegmann T, Ciocon JO, Basile JN (2004) Cardiovascular outcomes using doxazosin vs. chlorthalidone for the treatment of hypertension in older adults with and without glucose disorders: a report from the ALLHAT study. J Clin Hypertens (Greenwich) 6: 116-125. https://doi.org/10.1111/j.1524-6175.2004.03216.x

140. Weber MA, Bakris GL, Jamerson K, Weir M, Kjeldsen SE, Devereux RB, Velazquez EJ, Dahlöf B, Kelly RY, Hua TA, Hester A, Pitt B (2010) Cardiovascular events during differing hypertension therapies in patients with diabetes. J Am Coll Cardiol 56:77-85. https://doi.org/10.1016/j.jacc. 2010.02.046

141. Palmer SC, Mavridis D, Navarese E, Craig JC, Tonelli M, Salanti G, Wiebe N, Ruospo M, Wheeler DC, Strippoli GFM (2015) Comparative efficacy and safety of blood pressure-lowering agents in adults with diabetes and kidney disease: a network meta-analysis. Lancet 385:2047-2056. https://doi.org/10. 1016/S0140-6736(14)62459-4

142. Catalá-López F, Macías Saint-Gerons D, González-Bermejo D, Rosano GM, Davis BR, Ridao M, Zaragoza A, Montero-Corominas D, Tobías A, de la Fuente-Honrubia C, Tabarés-Seisdedos R, Hutton B (2016) Cardiovascular and renal outcomes of renin-angiotensin system blockade in adult patients with diabetes mellitus: a systematic review with network meta-analyses. Plos Med 13:e1001971. https://doi.org/10.1371/journal.pmed.1001971

143. Turner R, Holman R, Stratton I, Cull C, Frighi V, Manley S, Matthews D, Neil A, McElroy H, Kohner E, Fox C, Hadden D, Wright D (1998) Tight blood pressure control and risk of macrovascular and microvascular complications 
in type 2 diabetes: UKPDS 38. Br Med J 317:703-713. https://doi.org/10. 1136/bmj.317.7160.703

144. Cushman WC, Evans GW, Byington RP, Goff DC, Grimm RH, Cutler JA, Simons-Morton DG, Basile JN, Corson MA, Probstfield JL, Katz L, Peterson KA, Friedewald WT, Buse JB, Bigger JT, Gerstein HC, Ismail-Beigi F (2010) Effects of intensive blood-pressure control in type 2 diabetes mellitus. N Engl J Med 362:1575-1585. https://doi.org/10.1056/NEJMoa1001286

145. Kaur R, Kaur M, Singh J (2018) Endothelial dysfunction and platelet hyperactivity in type 2 diabetes mellitus: molecular insights and therapeutic strategies. Cardiovasc Diabetol. 17:121

146. Klein S, Sheard NF, Pi-Sunyer X, Daly A, Wylie-Rosett J, Kulkarni K, Clark NG (2004) Weight management through lifestyle modification for the prevention and management of type 2 diabetes: rationale and strategies - a statement of the American Diabetes Association, the North American Association for the Study of Obesity, and the American S. Diabetes Care 27: 2067-2073

147. Wing RR, Lang W, Wadden TA, Safford M, Knowler WC, Bertoni AG, Hill JO, Brancati FL, Peters A, Wagenknecht L (2011) Benefits of modest weight loss in improving cardiovascular risk factors in overweight and obese individuals with type 2 diabetes. Diabetes Care 34:1481-1486. https://doi.org/10.2337/ dc10-2415

148. Jialal I, Vikram N (2017) Nutrition therapy for diabetes: implications for decreasing cardiovascular complications. J. Diabetes Complications 31:14771480

149. Grundy SM, Stone NJ, Bailey AL, Beam C, Birtcher KK, Blumenthal RS, Braun LT, De Ferranti S, Faiella-Tommasino J, Forman DE, Goldberg R, Heidenreich PA, Hlatky MA, Jones DW, Lloyd-Jones D, Lopez-Pajares N, Ndumele CE, Orringer CE, Peralta CA, Saseen JJ, Smith SC, Sperling L, Virani SS, Yeboah J (2019) 2018 AHA/ACC/AACVPR/AAPA/ABC/ACPM/ADA/AGS/APhA/ASPC/ NLA/PCNA guideline on the management of blood cholesterol: a report of the American College of Cardiology/American Heart Association Task Force on Clinical Practice Guidelines. Circulation 139:E1082-E1143

150. Colhoun HM, Betteridge DJ, Durrington PN, Hitman GA, Neil HAW, Livingstone SJ, Thomason MJ, Mackness Ml, Charlton-Menys V, Fuller JH (2004) Primary prevention of cardiovascular disease with atorvastatin in type 2 diabetes in the Collaborative Atorvastatin Diabetes Study (CARDS): multicentre randomised placebo-controlled trial. Lancet 364:685-696. https://doi.org/10.1016/S0140-6736(04)16895-5

151. LaRosa JC, Grundy SM, Waters DD, Shear C, Barter P, Fruchart JC, Gotto AM, Greten H, Kastelein JJP, Shepherd J, Wenger NK (2005) Intensive lipid lowering with atorvastatin in patients with stable coronary disease. N Engl J Med 352:1425-1435. https://doi.org/10.1056/NEJMoa050461

152. Brown BG, Zhao XQ, Chait A, Fisher LD, Cheung MC, Morse JS, Dowdy AA, Marino EK, Bolson EL, Alaupovic P, Frohlich J, Serafini L, Huss-Frechette E, Wang S, DeAngelis D, Dodek A, Albers JJ (2001) Simvastatin and niacin, antioxidant vitamins, or the combination for the prevention of coronary disease. N Engl J Med 345:1583-1592. https://doi.org/10.1056/ NEJMoa011090

153. Pop-Busui R, Low PA, Waberski BH, Martin CL, Albers JW, Feldman EL, Sommer C, Cleary PA, Lachin JM, Herman WH (2009) Effects of prior intensive insulin therapy on cardiac autonomic nervous system function in type 1 diabetes mellitus: the diabetes control and complications trial/ epidemiology of diabetes interventions and complications study (DCCT/ EDIC). Circulation 119:2886-2893. https://doi.org/10.1161/CIRCULATIONAHA. 108.837369

154. Pagidipati NJ, Navar AM, Pieper KS, Green JB, Bethel MA, Armstrong PW, Josse RG, McGuire DK, Lokhnygina Y, Cornel JH, Halvorsen S, Strandberg TE, Delibasi T, Holman RR, Peterson ED (2017) Secondary prevention of cardiovascular disease in patients with type 2 diabetes mellitus: international insights from the TECOS trial (trial evaluating cardiovascular outcomes with sitagliptin). Circulation 136:1193-1203. https://doi.org/10. 1161/CIRCULATIONAHA.117.027252

155. Vinik Al, Ziegler D (2007) Diabetic cardiovascular autonomic neuropathy. Circulation 115:387-397

156. Cardiomyopathy | NHLBI, NIH. https:/www.nhlbi.nih.gov/health-topics/ cardiomyopathy. Accessed 6 Sept 2020

157. Huynh K, Bernardo BC, McMullen JR, Ritchie RH (2014) Diabetic cardiomyopathy: mechanisms and new treatment strategies targeting antioxidant signaling pathways. Pharmacol. Ther. 142:375-415

158. Dahlén EM, Tengblad A, Länne T, Clinchy B, Ernerudh J, Nystrom FH, Östgren CJ (2014) Abdominal obesity and low-grade systemic inflammation as markers of subclinical organ damage in type 2 diabetes. Diabetes Metab 40:76-81. https://doi.org/10.1016/j.diabet.2013.10.006

159. Qiao L, Li X (2014) Role of chronic inflammation in cancers of the gastrointestinal system and the liver: where we are now. Cancer Lett 345:150-152

160. Steinberg GR, Schertzer JD (2014) AMPK promotes macrophage fatty acid oxidative metabolism to mitigate inflammation: Implications for diabetes and cardiovascular disease. Immunol Cell Biol 92:340-345

161. Costa AGV, Garcia-Diaz DF, Jimenez P, Silva PI (2013) Bioactive compounds and health benefits of exotic tropical red-black berries. J Funct Foods 5:539-549

162. Hutchins-Wolfbrandt A, Mistry AM (2011) Dietary turmeric potentially reduces the risk of cancer. Asian Pac J Cancer Prev 12:3169-3173

163. Alves NEG, Enes BN, Martino HSD, Alfenas RDCG, Ribeiro SMR (2014) Meal replacement based on human ration modulates metabolic risk factors during body weight loss: a randomized controlled trial. Eur J Nutr 53:939950. https://doi.org/10.1007/s00394-013-0598-3

164. Gironés-Vilaplana A, Moreno DA, García-Viguera C (2014) Phytochemistry and biological activity of Spanish citrus fruits. Food Funct 5:764-772. https:// doi.org/10.1039/c3fo60700c

165. Schreckinger ME, Wang J, Yousef G, Lila MA, De Mejia EG (2010) Antioxidant capacity and in vitro inhibition of adipogenesis and inflammation by phenolic extracts of Vaccinium floribundum and Aristotelia chilensis. J Agric Food Chem 58:8966-8976. https://doi.org/10.1021/jf100975m

166. Tinkov AA, Nemereshina ON, Popova EV, Polyakova VS, Gritsenko VA, Nikonorov AA (2014) Plantago maxima leaves extract inhibits adipogenic action of a high-fat diet in female Wistar rats. Eur J Nutr 53:831-842. https:// doi.org/10.1007/s00394-013-0587-6

167. Chuang CC, McIntosh MK (2011) Potential mechanisms by which polyphenol-rich grapes prevent obesity-mediated inflammation and metabolic diseases. Annu Rev Nutr 31:155-176. https://doi.org/10.1146/ annurev-nutr-072610-145149

168. Taing MW, Pierson JT, Hoang VLT, Shaw PN, Dietzgen RG, Gidley MJ, Roberts-Thomson SJ, Monteith GR (2012) Mango fruit peel and flesh extracts affect adipogenesis in 3T3-L1 cells. Food Funct 3:828-836. https:// doi.org/10.1039/c2fo30073g

169. Williams DJ, Edwards D, Hamernig I, Jian L, James AP, Johnson SK, Tapsell LC (2013) Vegetables containing phytochemicals with potential anti-obesity properties: a review. Food Res Int 52:323-333

170. Horsfield K, Cumming G (1968) Morphology of the bronchial tree in man. J Appl Physiol 24:373-383. https://doi.org/10.1152/jappl.1968.24.3.373

171. Appel LJ (2003) Effects of comprehensive lifestyle modification on blood pressure control: main results of the PREMIER clinical trial. J Am Med Assoc 289:2083-2093. https://doi.org/10.1001/jama.289.16.2083

172. Juraschek SP, Miller ER, Weaver CM, Appel LJ (2017) Effects of sodium reduction and the DASH diet in relation to baseline blood pressure. J Am Coll Cardiol 70:2841-2848. https://doi.org/10.1016/j.jacc.2017.10.011

173. Young DR, Hivert MF, Alhassan S, Camhi SM, Ferguson JF, Katzmarzyk PT, Lewis CE, Owen N, Perry CK, Siddique J, Yong CM (2016) Sedentary behavior and cardiovascular morbidity and mortality: a science advisory from the American Heart Association. Circulation 134:e262-e279. https://doi. org/10.1161/CIR.0000000000000440

174. James PA, Oparil S, Carter BL, Cushman WC, Dennison-Himmelfarb C, Handler J, Lackland DT, LeFevre ML, MacKenzie TD, Ogedegbe O, Smith SC, Svetkey LP, Taler SJ, Townsend RR, Wright JT, Narva AS, Ortiz E (2014) 2014 Evidence-based guideline for the management of high blood pressure in adults: Report from the panel members appointed to the Eighth Joint National Committee (JNC 8). JAMA 311:507-520

175. Arauz-Pacheco C, Parrott MA, Raskin P (2002) The treatment of hypertension in adult patients with diabetes. Diabetes Care 25:134-147. https:/doi.org/10.2337/ diacare.25.1.134

176. Brook RD, Appel $\sqcup$, Rubenfire M, Ogedegbe G, Bisognano JD, Elliott WJ, Fuchs FD, Hughes JW, Lackland DT, Staffileno BA, Townsend RR, Rajagopalan S (2013) Beyond medications and diet: alternative approaches to lowering blood pressure: a scientific statement from the American Heart Association. Hypertension 61:1360-1383. https://doi.org/10.1161/HYP.0b013e318293645f

177. Colberg SR, Sigal RJ, Yardley JE, Riddell MC, Dunstan DW, Dempsey PC, Horton ES, Castorino K, Tate DF (2016) Physical activity/exercise and diabetes: a position statement of the American Diabetes Association. Diabetes Care 39:2065-2079

178. Semlitsch T, Jeitler K, Berghold A, Horvath K, Posch N, Poggenburg S (2016) Siebenhofer A (2016) Long-term effects of weight-reducing diets in people with hypertension. Cochrane Database Syst Rev 3(3):CD008274 
179. Shaw JE, Punjabi NM, Naughton MT, Willes L, Bergenstal RM, Cistulli PA, Fulcher GR, Richards GN, Zimmet PZ (2016) The effect of treatment of obstructive sleep apnea on glycemic control in type 2 diabetes. Am J Respir Crit Care Med 194:486-492. https://doi.org/10.1164/rccm.201511-22600C

180. Association AD (2019) 15. Diabetes care in the hospital: standards of medical care in diabetes 2019. Diabetes Care 42:S173-S181. https://doi.org/ 10.2337/dc19-S015

181. Wu L, Piotrowski K, Rau T, Waldmann E, Broedl UC, Demmelmair H, Koletzko B, Stark RG, Nagel JM, Mantzoros CS, Parhofer KG (2014) Walnut-enriched diet reduces fasting non-hdl-cholesterol and apolipoprotein B in healthy caucasian subjects: a randomized controlled cross-over clinical trial. Metabolism 63:382-391. https://doi.org/10.1016/j.metabol.2013.11.005

182. Franks PW, Pearson E, Florez JC (2013) Gene-environment and genetreatment interactions in type 2 diabetes: progress, pitfalls, and prospects. Diabetes Care 36:1413-1421

183. Reinehr T, Friedel S, Mueller TD, Toschke AM, Hebebrand J, Hinney A (2008) Evidence for an influence of TCF7L2 polymorphism rs7903146 on insulin resistance and sensitivity indices in overweight children and adolescents during a lifestyle intervention. Int J Obes 32:1521-1524. https://doi.org/10. 1038/ijo.2008.146

184. Cornelis MC, Hu FB (2012) Gene-environment interactions in the development of type 2 diabetes: recent progress and continuing challenges. Annu Rev Nutr. 32:245-259

185. TO K, Qi L, Brage S, Sharp SJ, Sonestedt E, Demerath E, Ahmad T, Mora S, Kaakinen M, Sandholt CH, Holzapfel C, Autenrieth CS, Hyppönen E, Cauchi S, He M, Kutalik Z, Kumari M, Stančáková A, Meidtner K, Balkau B, Tan JT, Mangino M, Timpson NJ, Song Y, Zillikens MC, Jablonski KA, Garcia ME, Johansson S, Bragg-Gresham JL, Wu Y, van Vliet-Ostaptchouk JV, OnlandMoret NC (2011) Physical activity attenuates the influence of FTO variants on obesity risk: a meta-analysis of 218,166 adults and 19,268 children. Plos Med 8:e1001116. https://doi.org/10.1371/journal.pmed.1001116

186. Nettleton JA, McKeown NM, Kanoni S, Lemaitre RN, Hivert MF, Ngwa J, Van Rooij FJA, Sonestedt E, Wojczynski MK, Ye Z, Tanaka T, Garcia M, Anderson JS, Follis JL, Djousse L, Mukamal K, Papoutsakis C, Mozaffarian D, Zillikens MC, Bandinelli S, Bennett AJ, Borecki IB, Feitosa MF, Ferrucci L, Forouhi NG, Groves CJ (2010) Interactions of dietary whole-grain intake with fasting glucose- and insulin-related genetic loci in individuals of European descent: a meta-analysis of 14 cohort studies. Diabetes Care 33:2684-2691

187. Zhang Y, Guo X, Guo J, He Q, Li H, Song Y, Zhang H (2014) Lactobacillus casei reduces susceptibility to type 2 diabetes via microbiota-mediated body chloride ion influx. Sci Rep 4:1-10. https://doi.org/10.1038/srep05654

188. Kim MG, Elizabeth R, Claudia WB, Judith WR, Jerome M, Charles E (2003) REAP and WAVE: New Tools to Rapidly Assess/Discuss Nutrition with Patients. J Nutrition 133(2);556S-562S.

189. Evert AB, Dennison M, Gardner CD, Timothy Garvey W, Karen Lau KH, MacLeod J, Mitri J, Pereira RF, Rawlings K, Robinson S, Saslow L, Uelmen S, Urbanski PB, Yancy WS (2019) Nutrition therapy for adults with diabetes or prediabetes: a consensus report. Diabetes Care 42:731-754

190. Daly A, Michael P, Johnson EQ, Harrington CC, Patrick S, Bender T (2009) Diabetes white paper: defining the delivery of nutrition services in medicare medical nutrition therapy vs medicare diabetes self-management training programs. J Am Diet Assoc 109:528-539. https://doi.org/10.1016/j.jada.2008. 11.004

191. Pastors JG, Warshaw H, Daly A, Franz M, Kulkarni K (2002) The evidence for the effectiveness of medical nutrition therapy in diabetes management. Diabetes Care 25:608-613

192. Bailey CJ, Grant PJ, Evans M, De Fine ON, Andreasen AH, Fowler PBS, Good CB, Turner RC, Holman R, Stratton I, Kerner W (1998) The UK prospective diabetes study (multiple letters) [1]. Lancet 352:1932-1934

193. Cholesterol Treatment Trialists' (CTT) Collaborators (2008) Efficacy of cholesterol-lowering therapy in 18686 people with diabetes in 14 randomised trials of statins: a meta-analysis. Lancet 371:117-125. https://doi. org/10.1016/S0140-6736(08)60104-X

194. Program NHBPE (2004) The Seventh Report of the Joint National Committee on Prevention, Detection, Evaluation, and Treatment of High Blood Pressure. National Heart, Lung, and Blood Institute (US). United States

195. Franz MJ, Powers MA, Leontos C, Holzmeister LA, Kulkarni K, Monk A, Wedel N, Gradwell E (2010) The evidence for medical nutrition therapy for type 1 and type 2 diabetes in adults. J Am Diet Assoc 110:1852-1889. https://doi. org/10.1016/j.jada.2010.09.014
196. Al-Shookri A, Khor GL, Chan YM, Loke SC, Al-Maskari M (2012) Effectiveness of medical nutrition treatment delivered by dietitians on glycaemic outcomes and lipid profiles of Arab, Omani patients with type 2 diabetes. Diabet Med 29:236-244. https://doi.org/10.1111/j.1464-5491.2011.03405.x

197. Amiel S, Beveridge S, Bradley C, Gianfrancesco C, Heller S, James P, McKeown N, Newton L, Newton D, Oliver L, Reid H, Roberts S, Robson S, Rollingson J, Scott V, Speight J, Taylor C, Thompson G, Turner E, Wright F (2002) Training in flexible, intensive insulin management to enable dietary freedom in people with type 1 diabetes: dose adjustment for normal eating (DAFNE) randomised controlled trial. Br Med J 325:746-749. https://doi.org/ 10.1136/bmj.325.7367.746

198. Suresh S, Pathak S (2005) Chronotherapeutics: emerging role of biorhythms in optimizing drug therapy. Indian J. Pharm. Sci. 67:135-140

199. Karlsson B, Knutsson A, Lindahl B (2001) Is there an association between shift work and having a metabolic syndrome? Results from a population based study of 27485 people. Occup Environ Med 58:747-752. https://doi. org/10.1136/oem.58.11.747

200. Scheer FAJL, Hilton MF, Mantzoros CS, Shea SA (2009) Adverse metabolic and cardiovascular consequences of circadian misalignment. Proc Natl Acad Sci U S A 106:4453-4458. https://doi.org/10.1073/pnas.0808180106

201. Carroll MF, Hardy KJ, Burge MR, Schade DS (2002) Frequency of the dawn phenomenon in type 2 diabetes: implications for diabetes therapy. Diabetes Technol Ther 4:595-605. https://doi.org/10.1089/152091502320798213

202. Kandaswamy E, Zuo L (2018) Recent advances in treatment of coronary artery disease: role of science and technology. Int J Mol Sci 19(2):424

203. Forrestel AC, Miedlich SU, Yurcheshen M, Wittlin SD, Sellix MT (2017) Chronomedicine and type 2 diabetes: shining some light on melatonin. Diabetologia 60:808-822

204. Turner RC, Holman RR, Matthews DR, Oakes SF, Bassett RA, Stratton IM, Cull CA, Manley SE, Frighi V (1991) UK prospective diabetes study (UKPDS) - VIII. Study design, progress and performance. Diabetologia 34:877-890. https:// doi.org/10.1007/BF00400195

205. Nathan DM (2014) The diabetes control and complications trial/ epidemiology of diabetes interventions and complications study at 30 years: overview. Diabetes Care 37:9-16. https://doi.org/10.2337/dc13-2112

206. Vaccaro O, Franzini L, Miccoli R, Cavalot F, Ardigò D, Boemi M, De Feo P, Reboldi G, Rivellese AA, Trovati M, Zavaroni I (2013) Feasibility and effectiveness in clinical practice of a multifactorial intervention for the reduction of cardiovascular risk in patients with type 2 diabetes: the 2-year interim analysis of the MIND.IT study: a cluster randomized trial. Diabetes Care 36:2566-2572. https://doi.org/10.2337/dc12-1781

207. Sun L, Yu M, Zhou T, Zhang S, He G, Wang G, Gang X (2019) Current advances in the study of diabetic cardiomyopathy: from clinicopathological features to molecular therapeutics (review). Mol Med Rep 20:2051-2062. https://doi.org/10.3892/mmr.2019.10473

208. Cannon CP, Blazing MA, Giugliano RP, McCagg A, White JA, Theroux P, Darius H, Lewis BS, TO O, Jukema JW, De Ferrari GM, Ruzyllo W, De Lucca P, Im KA, Bohula EA, Reist C, Wiviott SD, Tershakovec AM, Musliner TA (2015) Ezetimibe added to statin therapy after acute coronary syndromes. N Engl J Med 372:2387-2397. https://doi.org/10.1056/NEJMoa1410489

\section{Publisher's Note}

Springer Nature remains neutral with regard to jurisdictional claims in published maps and institutional affiliations. 